\title{
The Influence of 3D Printing on Global Container Multimodal Transport System
}

\author{
Zhen Chen ${ }^{1,2}$ \\ ${ }^{1}$ Business School, Lingnan Normal University, Zhanjiang 524048, China \\ ${ }^{2}$ South China Sea Silk Road Collaborative Innovation Centre, Lingnan Normal University, Zhanjiang 524048, China
}

Correspondence should be addressed to Zhen Chen; lingnanchenzhen@qq.com

Received 23 August 2017; Revised 12 October 2017; Accepted 16 October 2017; Published 6 November 2017

Academic Editor: Salvatore Cannella

Copyright (c) 2017 Zhen Chen. This is an open access article distributed under the Creative Commons Attribution License, which permits unrestricted use, distribution, and reproduction in any medium, provided the original work is properly cited.

\begin{abstract}
Container multimodal transport system was an important promoter of postwar globalization. But in the future, part of global manufacturing may change from centralized to distributed due to 3D printing. To evaluate its impact, this research established a system dynamics model of sneakers supply chain firstly. The modeling showed that the total demand of international transport would decline after the application of 3D printing. For consumer country, the return of manufacturing would increase its container business. And that of producer country would reduce correspondingly. But for resource country, its resource exports would decline, while its container business may grow for the local processing of printing filaments. Secondly, the evaluations based on the data of Guangzhou port suggest that the 3D printing of sneakers was not enough to subvert the existing system. It would be broken only after the 3D printing of electrical products. By then, more manufacturing activities would transfer to the end of supply chain. On the other hand, producer country may actively respond to maintain its advantage in incumbent industrial pattern, such as Belt and Road initiative proposed by China. Deglobalization, caused by 3D printing, and globalization strengthening, caused by trade cooperation, will affect this system simultaneously.
\end{abstract}

\section{Introduction}

Container was one of the most important logistics inventions in the 20th Century. Levinson (2008) reviewed that this magic box was born in the United States (US) industrial booming after World War II. It was firstly applied in domestic coastal routes by Sea Land Company and Mattson Company and then quickly changed the traditional transport mode. Since 1960s, frequent trade activity between the United States and Europe has led to acceptance of this efficient logistics tool in most of European ports. With the Japanese product marketing in the western world in 1970s and the US Defense Department on the promotion of military containers in the Vietnam War, the initial Pacific Rim route US-Vietnam-Japan is gradually shaped. On the basis of the Atlantic and Pacific routes, container logistics has spread all over the world [1]. This simple box obviously shortens the loading-unloading time of the goods and compresses the transshipment links. In order to give full play to its potential, the International Standardization Organization (IMO) has developed a global size standard for it, which improves the efficiency of container logistics system and expands the scope of application of containers.

To fill up a huge container ship, the necessary labor force is very small, and the time required is only about half of that required for a small traditional ship to be loaded in 1960s. With containers, a small number of crew members can easily manage an ocean ship which is bigger than three football pitches. A driver can put down a trailer at the dock and then hang another one and drive away. He does not have to wait for the goods unloading from the container. Qingdao, Rotterdam, and other large ports have even realized the automatic loading and unloading of containers in the yard. That can reduce the interference of human factors. Transportation has become so efficient that freight costs will largely not have much impact on multinational production decisions.

Container can not only reduce transportation costs, but also save time. After combining the computer tracking management system into container, the multinational enterprises have developed the production mode of Just in Time (JIT) in the global scale. JIT was developed by Japanese car 
manufacturers firstly. And before container used, JIT was implemented only within the territory of Japan. Container realized the accuracy of the global flow of goods, significantly reducing the inventory of manufacturers and transshipment links. This promoted a longer supply chain so that buyers can safely place orders to the other side of the earth. The multimodal transport system based on container has combined ships, railways, and roads together to achieve global manufacturing and sales of goods.

Container transport has developed into a global scale, highly automated, and standardized industry today. For decades, container and a series of industrial modes derived from it have profoundly changed our world. In the international industry relayout, as container reduced the threshold of international logistics, the labor-intensive industries have gradually shifted from developed countries to developing ones with lower labor costs. After being manufactured in these countries, finished products were shipped all over the world by high-speed container liners. The global industry is evolving into a "resource-producer-consumer" pattern. The geographical distance between consumption and production is longer and longer. In order to maintain the competitiveness of producer countries in the international industrial layout, they are always upgrading their ports, highways, railways, and other container infrastructures, such as China, Korea, and ASEAN. Countries that lack container infrastructure are fixed as the role of the resource countries, such as Africa and South America. The infrastructures in these countries are more designed for the export of raw resources, such as crude oil pipe and minerals convey belt, rather than goods suitable for container shipment, such as semiproducts and finished products.

Upgrading a region's existing container infrastructure and conveyance requires a large amount of continued investment. This makes the current international industrial structure difficult to change in a short time. But that does not mean it is a permanent situation. We can review the case of digital camera that digital imaging technology rapidly and profoundly changed the way how people use camera. Some disruptive innovations, such as $3 \mathrm{D}$ printing (3DP), will probably break the existing supply chain mode. $3 \mathrm{DP}$, or called additive manufacturing, is a digital manufacturing technology. Through a universal manufacturing machine, it can directly transform a digital file into a physical product. That means being free of customization and flexibility. It requires neither tools nor molds to produce the complex geometric structure. This also eliminates redundant assembly and reduces manual activities in the manufacturing process (Weller et al., 2015) [2]. It is drilling into the current system in some forms and gradually affecting the current container logistics. Then it may subvert the current global industrial division. The direction, velocity, and volume of global commodity flow may change dramatically.

Tien (2011) and Berman (2012) believed that 3DP and other digital technologies could combine together and let everyone participate in the manufacturing of goods through online platform $[3,4]$. The main production paradigm would shift from the producer-centric mass production to the consumer-centric mass customization. Zeleny (2012) proposed that future manufacturing would not happen in the other side of the earth but around the consumers themselves. People could meet their material needs of daily work and life by using 3D printers and various printing materials, such as plastic filament and metal powder [5]. When 3DP has developed to this stage, the existing global industrial structure will be seriously impacted. While international container logistics system and globalization complement each other, globalization was derived from centralized production. Does centralized production transforming into distributed production mean that container will die out in the future?

\section{Review of 3DP}

3DP is a generic term for a variety of rapid prototyping technologies, such as Fused Deposition Modeling (FDM) and Stereo Lithography Apparatus (SLA) for plastic printing and Selective Laser Sintering (SLS) for metal printing. It was originally only for industrial product prototyping. In recent years, this technology has made a great breakthrough in the use of various materials. Industry began to use 3DP to make components and even finished products, but they have not formed scale yet. Now industry and academia are committed to explore its application of feasible models, both at the industrial level and at the personal level.

2.1. 3DP at Industrial and Personal Levels. In what circumstances will the factory executives choose 3DP? Scott and Harrison (2015) investigated and compared several factors in the manufacturing process, including total demand, factory operating cost, product variable cost, processing time, 3DP equipment efficiency, and printing filament cost. They found that total demand was a key factor in deciding whether to adopt 3DP, and the decline of filament cost would promote the 3DP application obviously [6]. Khajavi et al. (2015) put forward that the combination of 3DP and conventional process could greatly reduce the risk of new product sales. Firstly a batch of 3DP samples were thrown into the market. If successful, the mass production with conventional technology would follow. This proved that sometimes 3DP and conventional process would not substitute but complement each other [7]. On the other hand, 3DP is more suitable for the manufacturing of spare parts. Ruffo et al. (2007) proposed that the decision of enterprises to purchase or print small batches of spare parts depends on the cost, capacity, knowledge, response, and quality of 3DP. Integrated various factors, self-printing was better for spare parts replacement, rather than ordering out [8]. Sirichakwal and Conner (2016) summarized that the use of 3DP could achieve the virtual inventory. This helped to reduce the stock-out probability and inventory obsolescence of spare parts [9].

The above researches are more concentrated within the producers. But 3DP features will allow more consumers to participate in the manufacturing of products, called "prosumer." Cautela et al. (2014) proposed that the current personal applications of 3DP were mainly from direct E-commerce, alliances with established distributors, and specialized retail channels. The role difference among manufacturers, 
distributors, and consumers was becoming blurred increasingly [10]. In recent years, with the expiration of a variety of patent and the emergence of open source application, the threshold of 3DP continues to decline. For the economic analysis of 3DP in home applications, Wittbrodt et al. (2013) carried out an experiment. In a whole year the experimenters used RepRap, a kind of open source printer, to manufacture 20 kinds of products to meet their daily needs instead of going to shop. The results showed that this behavior saved a lot of money [11]. This allowed the users of 3DP to expand from enterprises to individual hobbyists and creative customers (Laplume et al., 2016) [12]. 3DP business has allowed consumers to take over more jobs from producers. The manufacturer-consumer decoupling point would shift to upstream more than in conventional ones. It could not only meet the personal requirements but also achieve a leaner and agiler supply chain.

2.2. 3DP and Global Supply Chain. The application of 3DP has blurred the boundary between producers and consumers. The ordinary production mode is evolving from centralized to distributed one. That will gradually be transmitted from domestic to international scope, thus affecting the current layout of global industries (Gress and Kalafsky, 2015) [13]. Laplume et al. (2016) believed that if 3DP gets more applications, a considerable part of the incumbent manufacturing activities would flow out from Asia back to Europe and US. Not only was 3DP closer to the consumption location, but also it could save more human activities, so that the comparative advantage of human cost in Asia was no longer obvious. Moreover, the local use of 3DP would save a large amount of import tariffs and bypass the technical barriers in some consumer countries. This in part offsets the current high cost of printing materials [12]. And as 3DP applications continue to expand, the cost of materials would slowly decline. That in turn would promote $3 \mathrm{DP}$ to be further accepted by the public.

From the perspective of logistics and supply chain, the use of 3DP will greatly reduce the material consumption during the manufacturing process. Global freight volume will decrease and logistics network will face strategic contraction. Chen (2016) pointed out that relevant countries should carry out feasible measures, such as the reform of logistics facilities and the cooperation with origin country of printing materials, to face the challenge brought by 3DP [14]. In the 3DP era, no complex JIT distribution and no complicated raw material or product category management existed. Global logistics scheduling would not be difficult any more. The conventional logistics providers must get transition to enhance their core competitiveness. Dong et al. (2016) analyzed the case of UPS Company and proved that a logistics servicer was transforming to a logistics manufacturer under the 3DP circumstance. In order to respond to customer demand quickly, logistics companies needed to change their inventory structure. In addition to regular goods, their distribution centers were also required to store a variety of printing materials for immediate production of the necessary order, to avoid shortages [15].

\section{Research Idea}

According to the above research, 3DP, which was originally used for prototyping only, is now developing into a mainstream way of manufacturing. At the industrial level, many companies are considering the combinations of 3DP and traditional process to shorten the product lead time. At the personal level, private users are attempting to make daily necessities by 3DP. The incumbent pattern will turn from centralized production to distributed one. Since 3DP can greatly reduce the traditional processes such as turning, milling and grinding, and the use of molds, the transportation of materials during the manufacturing process will decrease significantly. Traditional distribution servicers will be required to provide real-time print service of urgent goods.

At present, the mainstream 3DP material cost is relatively high. Its printing speed is also slow. This hinders the further popularization of this technology. But RepRap's case (Wittbrodt et al., 2013) showed that while consumers spent more on materials, they saved time and other costs to get goods [11]. In general, some niche goods with lower demand, especially personalized products and spare parts, are ideal for 3DP, which only needs to be produced of one or several unique pieces in a short time. Similarly, 3DP is also applied to some regular goods requiring to be more personalized, such as clothing, shoes, toys, and even houses. They have not become a scale yet. But their manufactures are constantly forging ahead. When 3DP matures, 3DP may be a powerful substitute of conventional process. Will the current industrial structure be affected? What about the evolution trend of global container multimodal transport system?

For different materials, the printing cost varies. For example, SLS for printing metals is quite expensive. The cost of printer and metal powder is many times that of conventional process. So it is generally used in the manufacturing of highvalue components, such as aviation parts. In the short term, 3DP metal product is difficult to mass spread. Therefore, this research is more inclined to study the plastic resin product, which is cheaper and more mature.

3DP is more suitable to manufacturing the goods made of a single material. In recent years, with consumer demand for personalized products, they have become less satisfied with the regular styles of sneakers. Nike, Adidas, New Balance, and other transnational sports giants have been committed to the development of 3DP sneakers. These products are usually made of one or a few types of artificial plastics and their printing technology is FDM or SLA. Customers provided their foot size to the sneaker manufacturer and finally received their orders by real-time 3DP through the distributors. Because it was customized, the price was relatively high. And these orders have not been commissioned to the oversea foundry but the local 3DP workshop. The 3DP sneakers' accuracy is $\mathrm{OK}$, but the speed and cost cannot match the requirements of mass production yet. This model is more like concept marketing and not so popular among the ordinary people.

In 2017, Carbon, which was a start-up company in Silicon Valley, cooperated with Adidas Company and developed the Continuous Liquid Interface Production (CLIP) technology to optimize the process of sneakers in collaboration with 
sports manufacturers. It could reduce the printing time of sneakers from 1.5 hours to 20 minutes. This greatly improved the productivity of 3DP sneakers. Adidas hoped to sell 5,000 pairs in 2017. And the annual sales volume could expand to 100,000 pairs in the future when the production times were shortened (Vincent, 2017) [16]. This is only a small amount compared to Adidas's annual sales of 100,000,000 pairs, but with the further development of 3DP technology and the promotion of consumer personalized requirement, sneakers may be the first product which are 3DP mass-customized in the foreseeable future. Therefore, this research focuses on the supply chain of 3DP sneakers.

3DP has not been large scale applied. The relevant data is lacking. Moreover, most of the existing achievements have focused on domestic scope. There is less quantitative research on the worldwide range. In order to evaluate the impact of 3DP on container multimodal transport system, it is necessary to analyze the evolution of transnational supply chain. Based on the case of 3DP sneakers, this research intends to establish a system dynamics model and then simulate possible scenarios and discuss the evolution of supply chain under these circumstances. Finally, the impacts of 3DP on the system are discussed based on the throughput data from a typical port in producer country.

System dynamics is a systematic simulation method to analyze the problems of production and inventory management. It is common in supply chain construction. Under the premise of insufficient data, the method can still predict conditional target variables by using flow diagrams which containing causal loops. Moreover, the flow diagram structure can intuitively reflect the operation process of the chain. Currently, 3DP related data is lacking. Therefore, system dynamics is viable to quantify the impact of $3 \mathrm{DP}$ on container multimodal transport system.

\section{Modeling of the Sneakers Supply Chain}

4.1. Traditional Supply Chain Model. The first step is to model the transnational supply chain of traditional sneakers. According to recent years' public data from Nike Company, it has $25 \%$ of employees and $10 \%$ of sales in China. In North America, it has about $1 \%$ of employees, but sales account for $50 \%$. In the Middle East, Russia, and other oil origin regions, the number of employees is $1 \%$, and the sales are only about $5 \%$. There is no doubt that, in the Nike sneakers industry chain, China is a producer country, US is a consumer country, and the Middle East plays the role of a resource region. Set the starting point of the chain as an oil field in the Middle East. Its production of oil is shipped to China and refined to form raw plastic and then processed into sneakers. Ultimately these finished products are shipped to US, China, and the Middle East for sale. Since the research is concerned more with the transnational changes of material transportation, the domestic distribution part is not the focus. Therefore, the local sneakers distribution centers in these three regions are set to be the supply chain terminals.

In the model setting the sneakers are made of one single plastic. The main steps of the whole supply chain are as follows.
TABLE 1: Variable symbol of transnational supply chain.

\begin{tabular}{lr}
\hline Symbol & Meaning of variables \\
$\begin{array}{l}\text { OfME } \\
\text { ReBG }\end{array}$ & An oil field in the Middle East \\
PoPR & A refinery around the Beibu Gulf \\
DcPR & A port in the Pearl River Delta \\
PoPG & A distribution centre in the Pearl River Delta \\
PfPR & A port in the Persian Gulf \\
PoWU & A plastic processing factory in the Pearl River Delta \\
DcUS & A port in the West US \\
PoBG & A distribution centre in the US \\
MfPR & A sneaker manufacturing factory in the Pearl River Delta \\
DcME & A distribution centre in the Middle East \\
\hline
\end{tabular}

(1) The crude is exploited from the oil field in the Middle East and transported to the depot of the Persian Gulf by pipeline.

(2) The crude is loaded on a tanker and goes to the Beibu Gulf in China, which is a petrochemical industry cluster. In a refinery in the Beibu Gulf, the crude is processed into raw plastic and then shipped by trailer to a plastic processing factory in the nearby Pearl River Delta, a main manufacturing cluster in China.

(3) The raw plastic is transformed into plastic particles, which is the basic material for many plastic products.

(4) A foundry there receives the order from Nike headquarter and purchases these required plastic particles for production. In this process, its transport vehicle is still trailer. Through the injection molding, cutting, sewing, and other processes, the sneakers are completely made.

(5) The finished products for US and the Middle East will be shipped out through a port in the Pearl River Delta. The sneakers destined for US will go to one of the western coastal ports and then to the local distribution center by road. The sneakers destined for the Middle East will arrive at a port in the Persian Gulf and then also to the local distribution center by road. The sneakers for China are directly transported from the foundry to the local distribution center by domestic road.

The model is established by the VENSIM PLE software. The variable meaning in the model is shown in Table 1.

Based on the descriptions that is shown in Table 1, the system dynamics model of traditional supply chain is shown in Figure 1. The supply chain in this scenario is called Scenario $T$.

The focus of this research is to evaluate the impact of $3 \mathrm{DP}$ on the container transport system. The parameter setting is concerned more with the differences among various kinds of vehicle but does not pay much attention to storage. In addition, the shortest length of the supply chain under different circumstances needs to be determined. That means that all the goods should not stay long at any node. After 


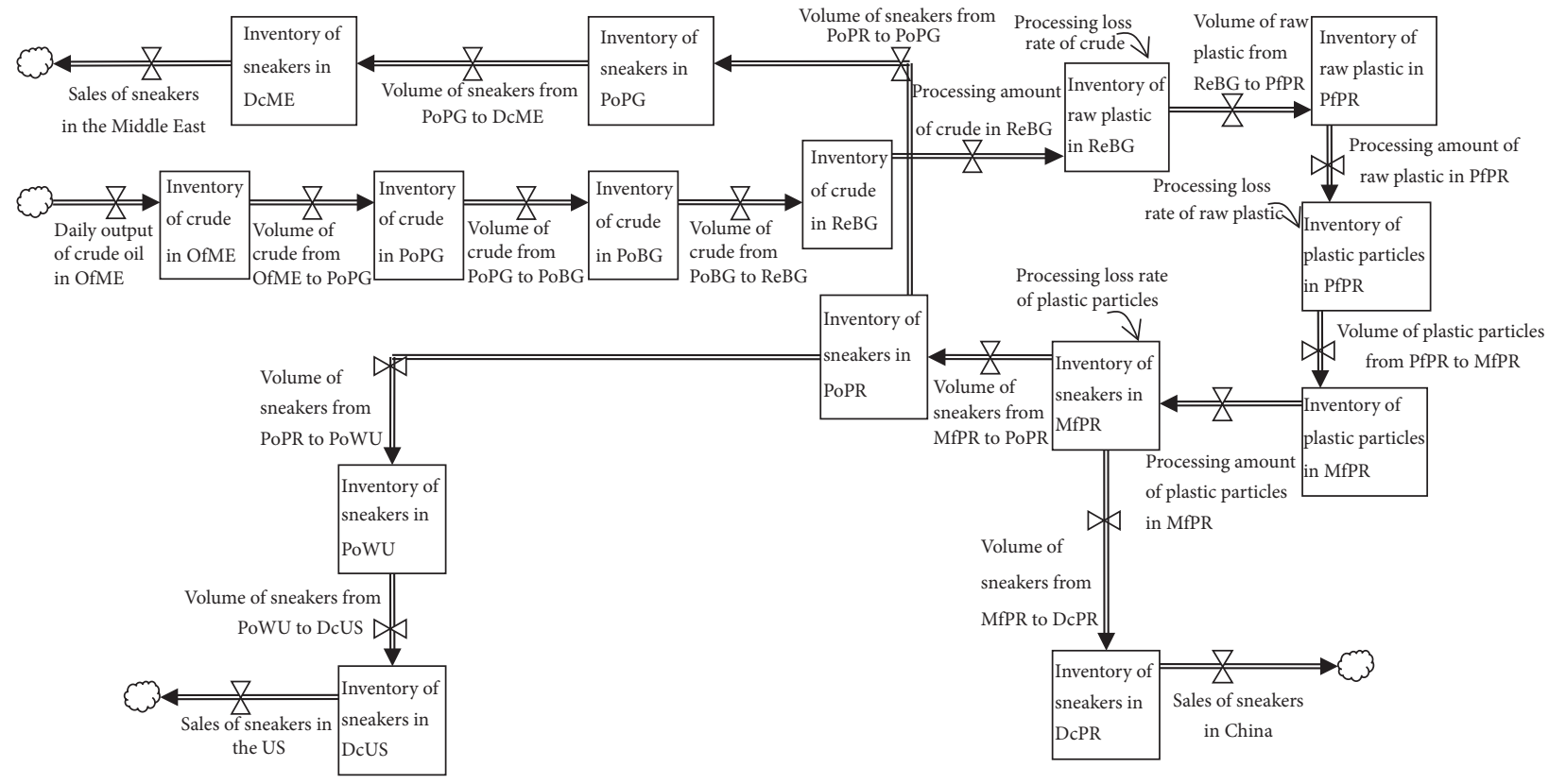

FIgURE 1: Flow diagram of supply chain in Scenario T.

TABLE 2: Setting of parameters in Scenario T.

\begin{tabular}{lc}
\hline Route & Transport mode and time spent \\
\hline OfME-PoPG & 3 days by pipeline \\
PoBG-ReBG & 1 day by pipeline \\
PfPR-MfPR & 1 day by trailer \\
PoPR-PoPG & 12 days by container vessel \\
PoPR-PoWU & 10 days by container vessel \\
MfPR-DcPR & 2 days by trailer \\
PoPG-PoBG & 15 days by tanker \\
ReBG-PfPR & 1 day by trailer \\
MfPR-PoPR & 1 day by trailer \\
PoPG-DcME & 2 days by trailer \\
PoWU-DcUS & 2 days by trailer \\
Time spent at each & The crude is loaded or unloaded at the port \\
node & for days. The rest of the goods are finished \\
& for about 1 day \\
\hline
\end{tabular}

the goods are ready for shipment they cannot remain in the same node for more than one day. According to the above setting, referring to actual geographical and transport data, the transportation mode and their time spent are shown in Table 2.

This is set to be a supply and demand equilibrium model. When the model runs, no excess inventory is in any node of the chain. Based on the sales data of Nike Company, 20 tons of the sneakers is sold per day in the three regions, including 15 tons sold in US, 4 tons in China, and 1 ton in the Middle East. According to field investigation data, the conversion rate of crude into raw plastic is $33.33 \%$. The conversion rate of raw plastic into plastic particles is $95.4 \%$. In the shoemaking process, there is some wastage such as leftover bits and pieces. And the conversion rate of plastic particles into sneakers is $87.5 \%$. In the circumstance of balanced supply and demand, the oil field in the Middle East produces 72 tons of crude per day to manufacture sneakers. Input the above data into the model and run the model simulation for 365 days. The result is shown in Table 3.

4.2. Future Scenarios and Matching Models. If the sneakers realize the $3 \mathrm{DP}$ production, the incumbent process will be completely overturned. The manufacturing activity in China will shift closer to the end consumer. Some studies have shown that consumers may choose to print the personal items at home, but the factory and workshop can provide the $3 \mathrm{DP}$ product with higher quality. That is because 3DP requires necessary postprocesses according to current technology. Nonprofessional consumer, if not able to cope, will reduce their experience. So it became complex to determine proper 3DP locations in the supply chain (Bogers et al., 2016) [17]. Sneakers are with a certain technical content. If printed by consumer themselves, they are not as good as from professional enterprises. Zeltmann et al. (2016) found that if 3DP was performed in a decentralized environment such as being homemade, there was risk of strength and durability in the finished product due to lack of qualified inspection [18]. The case of UPS Company (Dong et al., 2016) showed that in the 3DP era distribution provider is fully capable of acting as a qualified end-manufacturer [15]. Therefore, this model assumes the printing behavior of sneakers conducted in the local distribution centers of US, China, and the Middle East. The distribution centers get authorized and technical support from Nike Company. When they receive orders, they will print and deliver the product immediately. On the other hand, as a result of the shale gas revolution in recent years, 
TABLE 3: Simulation results of freight volume and period in Scenario T.

\begin{tabular}{|c|c|c|c|c|c|}
\hline Region & $\begin{array}{l}\text { Bulk freight by } \\
\text { land }\end{array}$ & $\begin{array}{c}\text { Container freight } \\
\text { by land }\end{array}$ & $\begin{array}{c}\text { Bulk port } \\
\text { throughput }\end{array}$ & $\begin{array}{c}\text { Container port } \\
\text { throughput }\end{array}$ & $\begin{array}{c}\text { Starting sales time of } \\
\text { sneakers }\end{array}$ \\
\hline Middle East & 26136 tons & 317 tons & 25848 tons & 317 tons & The 50th day \\
\hline US & 0 tons & 4785 tons & 0 tons & 4785 tons & The 48th day \\
\hline China & 24696 tons & 22437 tons & 24624 tons & 5280 tons & The 35th day \\
\hline \multicolumn{2}{|c|}{ Maritime route } & \multicolumn{2}{|c|}{ Bulk freight } & \multicolumn{2}{|c|}{ Container freight } \\
\hline \multicolumn{2}{|c|}{ Middle East-US } & \multicolumn{2}{|c|}{0 tons } & \multicolumn{2}{|c|}{0 tons } \\
\hline \multicolumn{2}{|c|}{ US-China } & \multicolumn{2}{|c|}{0 tons } & \multicolumn{2}{|c|}{4950 tons } \\
\hline \multicolumn{2}{|c|}{ China-Middle East } & \multicolumn{2}{|c|}{25776 tons } & \multicolumn{2}{|c|}{330 tons } \\
\hline
\end{tabular}

TABLE 4: Newly added variable symbol of transnational supply chain in Scenario 1.

\begin{tabular}{lc}
\hline Symbol & Meaning of variables \\
\hline PoGM & A port in the Gulf of Mexico \\
ReGM & A refinery around the Gulf of Mexico \\
PfUS & A plastic processing factory in US \\
\hline
\end{tabular}

US is likely to achieve self-sufficiency in the supply of crude. This means that the origin of crude is no more limited to the Middle East. Taking account of these possibilities, this research designed three extreme scenarios, called Scenario 1, Scenario 2, and Scenario 3. Among them, the origin of crude, the processing location of printing materials, and the region where sneakers are manufactured will change. The actual supply chain evolution may occur in the range among the three scenarios.

4.2.1. Simulation of Scenario 1. In Scenario 1, the origin of crude is still the Middle East. The materials used to make sneakers are no longer plastic particles, but special filaments for 3DP. Its production process is similar to plastic particles, which are manufactured by raw material in a processing factory. Since US and China have conducted a lot of investments in the research and development of 3DP for many years, such as "National Strategic Plan for Advanced Manufacturing" (2012) and "National Network for Manufacturing Innovation" (2012) in US and "Made in China 2025" (2015) and "National promoting plan of additive manufacturing" (2015) in China, this scenario sets that the locations of filament production are in US and China, respectively. The filaments made in US are for the sneakers of US consumers. And the filaments made in China are for the sneakers of China and the Middle East consumers. The crude for filament production is all from the Middle East. In Scenario 1, US is not only a consumer country, but also a filament producer. And its major crude unloading port and refinery cluster are around the Gulf of Mexico. Thus three new nodes are added. Their symbols are shown in Table 4.

In Scenario 1, the main steps of the whole supply chain have changed as follows.

(1) The crude is exploited from the oil field in the Middle East and transported by pipeline to the depot in the Persian Gulf.
(2) Different from Scenario T, the crude traffic is divided into two parts. One part is shipped to a port in the Gulf of Mexico and then refined to raw plastic and shipped by trailer to a plastic processing factory in US. The other is shipped to a port in the Beibu Gulf, also refined to raw plastic, and shipped by trailer to a plastic processing factory in the Pearl River Delta.

(3) The raw plastic is transformed into plastic filaments, which is the basic material for the 3DP of plastic. The model sets that the shipping way of filaments is container, no matter the container trailer by road or the container vessel by sea.

(4) Filaments made in US are shipped by trailer to a US distribution center. Filaments made in China are shipped to the distribution center in China by trailer and to the distribution center in the Middle East by container vessel, respectively.

(5) Nike headquarter informs the distribution centers to print and sends the sneakers in real time to the customers.

According to the above settings, the model is modified as shown in Figure 2.

Sneakers are not made in a shoe factory but printed directly in a distribution center. So the goods stay for 2 days at the distribution center, including printing and sorting, 1 day longer than that of Scenario T. The time spent in the newly added nodes is adjusted according to the actual investigated data. The remaining parameters of Scenario 1 are the same as those of Scenario T. Therefore, the transportation mode and their time spent are modified and shown in Table 5.

The sales per day of Scenario 1 are set the same as the one of Scenario T, 15 tons in US, 4 tons in China, and 1 ton in the Middle East. All kinds of materials have the same conversion rate in US and China. The conversion rate of crude into raw plastic is $33.33 \%$. The conversion rate of raw plastic into plastic filaments is $93.8 \%$. As the sneakers are made by $3 \mathrm{DP}$, the loss is greatly reduced to negligible extent. The model sets that the conversion rate of filaments into sneakers is $100 \%$. According to the setting, the crude shipped to US is 48 tons per day and generates 15 tons of filaments to the US distribution center. The crude shipped to China is 16 tons per day and generates 5 tons of filaments, in which 4 tons is shipped to China distribution center and 1 ton is shipped to 


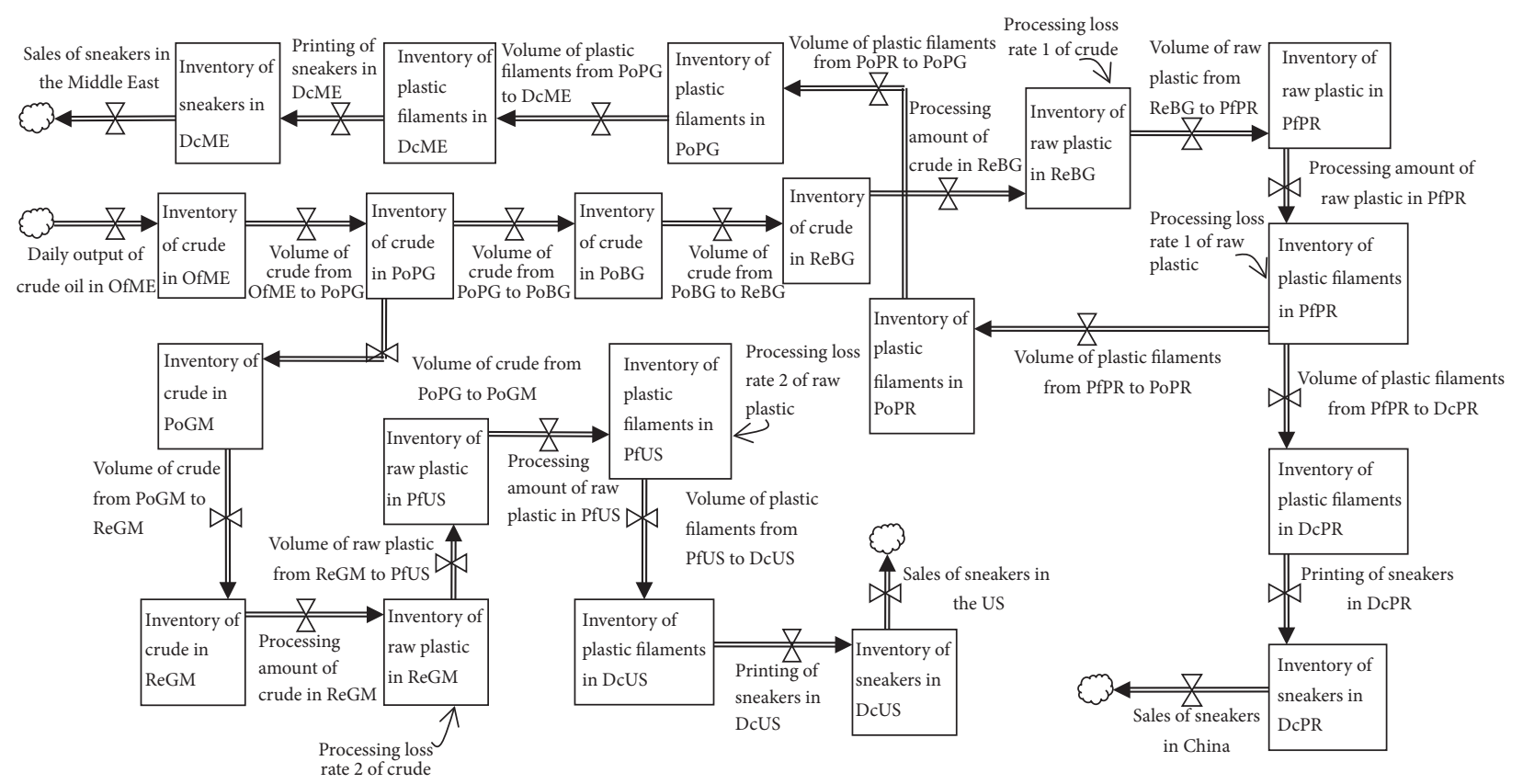

FIGURE 2: Flow diagram of supply chain in Scenario 1.

TABLE 5: Newly added setting of parameters in Scenario 1.

\begin{tabular}{lc}
\hline Route & Transport mode and time spent \\
\hline PoGM-ReGM & 2 days by pipeline \\
PfUS-DcUS & 2 days by trailer \\
PfPR-DcPR & 2 days by trailer \\
PoPG-PoGM & 37 days by tanker \\
ReGM-PfUS & 1 day by trailer \\
PfPR-PoPR & 1 day by trailer \\
Time spent in each & 2 days \\
distribution center & \\
\hline
\end{tabular}

the Middle East one. Input the above data into the model and run the model simulation for 365 days. The result is shown in Table 6.

4.2.2. Simulation of Scenario 2. Unlike Europe, US has gradually shifted from a typical crude consumer to a major producer because of the shale gas revolution in recent years. In Scenario 2, there are 2 origins of crude, the Middle East and US. The filaments used in China and the Middle East are processed by the crude from the Middle East. The filaments made in US are processed by the crude from US. The US origin area is still set around the Gulf of Mexico. Thus, add one new node into the Scenario model, an oil field in the Gulf of Mexico. Its symbol is OfGM. The crude oil passes through the pipeline to the nearby refinery, with a time spent of 2 days. Other settings remain the same as Scenario 1. The model is modified as shown in Figure 3.

The sales per day of Scenario 2 are set the same as the one of Scenario T, 15 tons in US, 4 tons in China, and 1 ton in the Middle East. The Middle East produces 16 tons of crude per day and ships it to China for manufacturing sneakers, while US produces 48 tons of crude per day locally. The other parameters of Scenario 2 and Scenario 1 are the same. Input the above data into the model and run the model simulation for 365 days. The result is shown in Table 7.

4.2.3. Simulation of Scenario 3. These years many regions have increased investment in the research and development of 3DP, including some countries in the Middle East. For example, Dubai, UAE, planned to build the whole nation into a global hub for 3DP by 2030. It majored in the industries of construction, medical products, and consumer goods. A market research institute, Future Market Insights, released a report (2016) predicting that from 2015 to 2025 the 3DP materials market in the Middle East will grow $16.7 \%$ per year [19]. In the foreseeable future some Middle East countries will probably get rid of the roles of resource country and be able to utilize 3DP technology to participate the international manufacturing more actively. Therefore, in Scenario 3 the Middle East will not export crude but process it into filaments and then export. In this case, in the Middle East the crude exploited from the oil field is firstly sent to a nearby refinery to transform into raw plastic. Then the raw plastic is transport by trailer to a plastic processing factory to produce filaments. Part of the filaments is shipped to the distribution center for local sneakers printing. The rest are shipped to Pearl River Delta port through the Persian Gulf port and finally reach a distribution center of China, which is used to make sneakers for Chinese customers. Add two new nodes to the model of Scenario 2. The settings of US remain the same. Their symbols are shown in Table 8.

The time spent in the newly added nodes is adjusted according to the actual investigated data. The remaining parameters of Scenario 3 are the same as those of Scenario 2. 
TABLE 6: Simulation results of freight volume and period in Scenario 1.

\begin{tabular}{|c|c|c|c|c|c|}
\hline Region & Bulk freight by land & $\begin{array}{l}\text { Container freight by } \\
\text { land }\end{array}$ & Bulk port throughput & $\begin{array}{c}\text { Container port } \\
\text { throughput }\end{array}$ & $\begin{array}{c}\text { Starting sales time of } \\
\text { sneakers }\end{array}$ \\
\hline Middle East & 23232 tons & 319 tons & 22976 tons & 321 tons & The 49th day \\
\hline US & 15408 tons & 9751 tons & 15408 tons & 0 tons & The 57th day \\
\hline China & 5488 tons & 3487 tons & 5472 tons & 334 tons & The 36th day \\
\hline \multicolumn{2}{|c|}{ Maritime route } & \multicolumn{2}{|c|}{ Bulk freight } & \multicolumn{2}{|c|}{ Container freight } \\
\hline \multicolumn{2}{|c|}{ Middle East-US } & \multicolumn{2}{|c|}{17184 tons } & \multicolumn{2}{|c|}{0 tons } \\
\hline \multicolumn{2}{|c|}{ US-China } & \multicolumn{2}{|c|}{0 tons } & \multicolumn{2}{|c|}{0 tons } \\
\hline \multicolumn{2}{|c|}{ China-Middle East } & \multicolumn{2}{|c|}{5728 tons } & \multicolumn{2}{|c|}{334 tons } \\
\hline
\end{tabular}

TABLE 7: Simulation results of freight volume and period in Scenario 2.

\begin{tabular}{|c|c|c|c|c|c|}
\hline Region & Bulk freight by land & $\begin{array}{l}\text { Container freight by } \\
\text { land }\end{array}$ & Bulk port throughput & $\begin{array}{c}\text { Container port } \\
\text { throughput }\end{array}$ & $\begin{array}{c}\text { Starting sales time of } \\
\text { sneakers }\end{array}$ \\
\hline Middle East & 5808 tons & 321 tons & 5744 tons & 321 tons & The 51st day \\
\hline US & 17424 tons & 11038 tons & 0 tons & 0 tons & The 16th day \\
\hline China & 5488 tons & 3487 tons & 5472 tons & 334 tons & The 36th day \\
\hline \multicolumn{2}{|c|}{ Maritime route } & \multicolumn{2}{|c|}{ Bulk freight } & \multicolumn{2}{|c|}{ Container freight } \\
\hline \multicolumn{2}{|c|}{ Middle East-US } & \multicolumn{2}{|c|}{0 tons } & \multicolumn{2}{|c|}{0 tons } \\
\hline \multicolumn{2}{|c|}{ US-China } & \multicolumn{2}{|c|}{0 tons } & \multicolumn{2}{|c|}{0 tons } \\
\hline \multicolumn{2}{|c|}{ China-Middle East } & \multicolumn{2}{|c|}{5728 tons } & \multicolumn{2}{|c|}{334 tons } \\
\hline
\end{tabular}

TABLE 8: Newly added variable symbol of transnational supply chain in Scenario 3.

\begin{tabular}{lc}
\hline Symbol & Meaning of variables \\
\hline ReME & A refinery in the Middle East \\
PfME & A plastic processing factory in the Middle East \\
\hline
\end{tabular}

TABLE 9: Newly added setting of parameters in Scenario 3.

\begin{tabular}{lc}
\hline Route & Transport mode and time spent \\
\hline OfME-ReME & 2 days by pipeline \\
PfME-DcME & 1 day by trailer \\
PoPG-PoPR & 12 days by container vessel \\
ReME-PfME & 1 day by trailer \\
PfME-PoPG & 2 days by trailer \\
\hline
\end{tabular}

Therefore, the transportation mode and their time spent are modified and shown in Table 9.

According to the above, the model is modified as shown in Figure 4.

The sales per day of Scenario 3 are set the same as the one of Scenario T, 15 tons in US, 4 tons in China, and 1 ton in the Middle East. The Middle East produces 16 tons of crude per day and ships it to China for manufacturing sneakers, while US produces 48 tons of crude per day locally. The other parameters of Scenario 3 and Scenario 2 are the same. Input the above data into the model and run the model simulation for 365 days. The result is shown in Table 10.

\section{Simulation Result Analysis}

In each scenario, there are two major transport ways in supply chain. The first one is bulk transport for crude, no matter by pipeline or tanker. The second one is container transport for semiproducts and finished plastic products, by vessel and trailer. According to Tables 3, 6, 7, and 10, Table 11 is established for comparing the simulation of four scenarios.

5.1. Flow Direction. For crude transportation, in Scenario 1 one part of crude is exported to US for filaments processing. This has facilitated the material flow within US territory and increased its port throughput. China's crude traffic is correspondingly reduced. But the Middle East remains the only resource exporter. In Scenario 2, US uses its own crude to process filaments. The oil of the Middle East is all exported to China. In Scenario 3, the Middle East enterprises made crude oil into filaments and then exported. The flow of crude only existed in the pipeline from oil fields to refineries. This proves that the 3DP distributed production will greatly shorten the global flow distance of primary raw materials. The unit freight turnover of primary raw materials will be significantly reduced.

For container transportation, Scenario 1 and Scenario 2 show that all semiproduct and finished plastic products of US circulate within the US territory. This will lead to the useless marine containers because of the non-trans-ocean transport. In the case of only domestic transport, it is likely that logistics providers are not willing to use container trailers but ordinary van to complete it, which has a more flexible demand response. In Scenario 3, the Middle East has become 


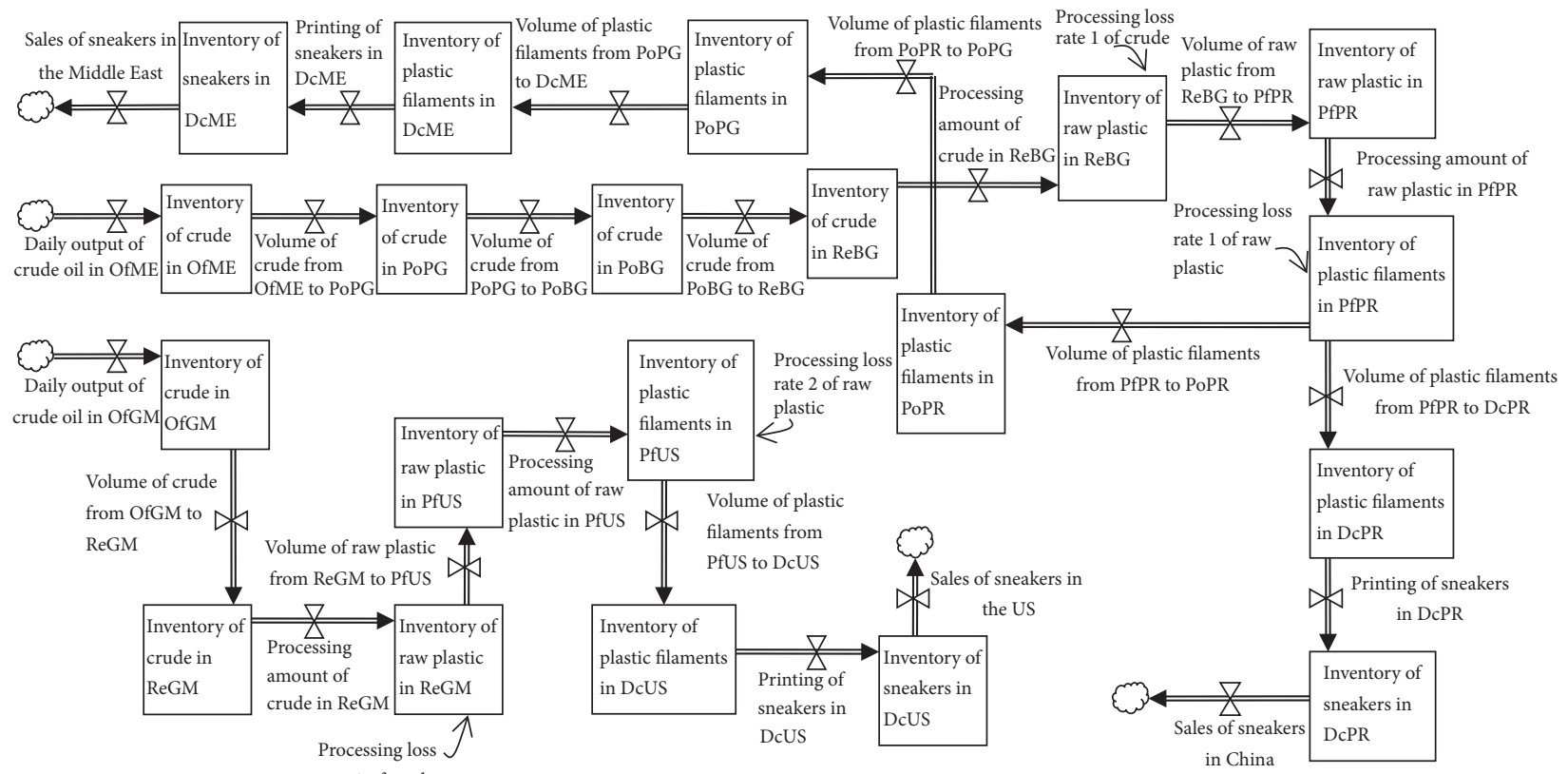

FIgURE 3: Flow diagram of supply chain in Scenario 2.

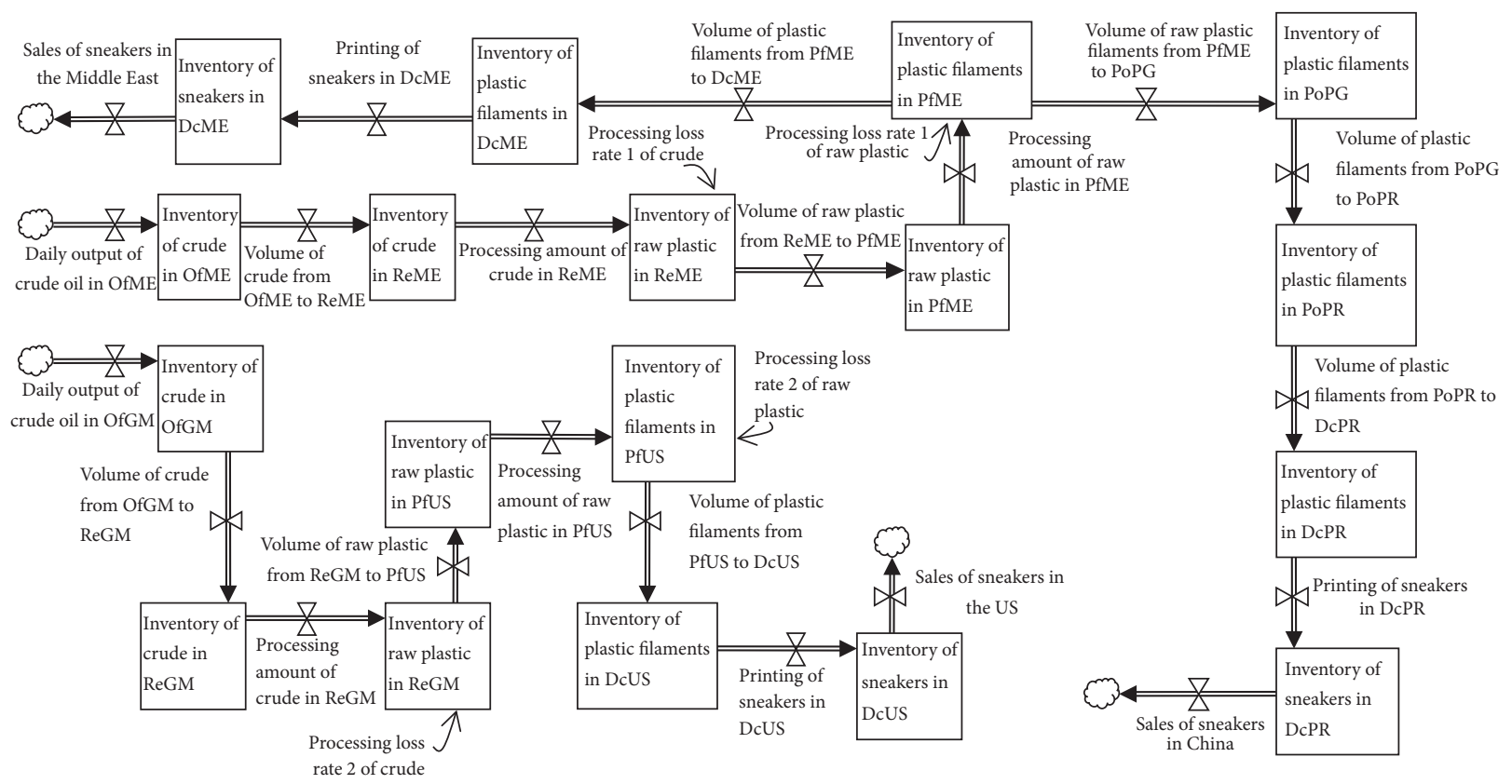

FIgURE 4: Flow diagram of supply chain in Scenario 3.

the exporter of filaments but not the importing region of sneakers. The container goods do not flow from China to the Middle East but in the opposite direction. On the one hand, the application of 3DP makes the countries which have both resource and consumer characteristics tend to circulate the business in domestic range. While container is more suitable for international multimodal transport, their use will decline if there is only domestic demand. On the other hand, the use of container in nonresource country can be maintained, because the transoceanic container of printing filaments is an efficient and punctual way to provide quick response to the demand of consumers in this digital era.

5.2. Flow Velocity. The faster the flow velocity, the shorter the start sales time of sneakers. In Scenario T, materials need to be transferred among multiple nodes and applied by several procedures. After 3DP application, the filaments generated by crude can be directly transported to the distribution center and printed according to the customer's order. The part of foundry manufacturing can be omitted, and there is no need 
TABLE 10: Simulation results of freight volume and period in Scenario 3.

\begin{tabular}{|c|c|c|c|c|c|}
\hline Region & Bulk freight by land & $\begin{array}{l}\text { Container freight by } \\
\text { land }\end{array}$ & Bulk port throughput & $\begin{array}{c}\text { Container port } \\
\text { throughput }\end{array}$ & $\begin{array}{c}\text { Starting sales time of } \\
\text { sneakers }\end{array}$ \\
\hline Middle East & 5808 tons & 2263 tons & 0 tons & 1404 tons & The 16th day \\
\hline US & 17424 tons & 11038 tons & 0 tons & 0 tons & The 16th day \\
\hline China & 0 tons & 1352 tons & 0 tons & 1352 tons & The 34th day \\
\hline \multicolumn{2}{|c|}{ Maritime route } & \multicolumn{2}{|c|}{ Bulk freight } & \multicolumn{2}{|c|}{ Container freight } \\
\hline \multicolumn{2}{|c|}{ Middle East-US } & \multicolumn{2}{|c|}{0 tons } & \multicolumn{2}{|c|}{0 tons } \\
\hline \multicolumn{2}{|c|}{ US-China } & \multicolumn{2}{|c|}{0 tons } & \multicolumn{2}{|c|}{0 tons } \\
\hline \multicolumn{2}{|c|}{ China-Middle East } & \multicolumn{2}{|c|}{0 tons } & \multicolumn{2}{|c|}{1404 tons } \\
\hline
\end{tabular}

TABLE 11: Comparison of simulation data of four scenarios.

\begin{tabular}{|c|c|c|c|c|c|}
\hline Region & $\begin{array}{l}\text { The volume of different } \\
\text { transport modes in } \\
\text { different locations }\end{array}$ & Scenario $\mathrm{T}$ & Scenario 1 & Scenario 2 & Scenario 3 \\
\hline \multirow{5}{*}{ Middle East } & Bulk freight by land & 26136 tons & 23232 tons & 5808 tons & 5808 tons \\
\hline & Container freight by land & 317 tons & 319 tons & 321 tons & 2263 tons \\
\hline & Bulk port throughput & 25848 tons & 22976 tons & 5744 tons & 0 tons \\
\hline & Container port throughput & 317 tons & 321 tons & 321 tons & 1404 tons \\
\hline & Start sales time of sneakers & The 50th day & The 49th day & The 51st day & The 16th day \\
\hline \multirow{5}{*}{ US } & Bulk freight by land & 0 tons & 15408 tons & 17424 tons & 17424 tons \\
\hline & Container freight by land & 4785 tons & 9751 tons & 11038 tons & 11038 tons \\
\hline & Bulk port throughput & 0 tons & 15408 tons & 0 tons & 0 tons \\
\hline & Container port throughput & 4785 tons & 0 tons & 0 tons & 0 tons \\
\hline & Start sales time of sneakers & The 48th day & The 57 th day & The 16th day & The 16th day \\
\hline \multirow{5}{*}{ China } & Bulk freight by land & 24696 tons & 5488 tons & 5488 tons & 0 tons \\
\hline & Container freight by land & 22437 tons & 3487 tons & 3487 tons & 1352 tons \\
\hline & Bulk port throughput & 24624 tons & 5472 tons & 5472 tons & 0 tons \\
\hline & Container port throughput & 5280 tons & 334 tons & 334 tons & 1352 tons \\
\hline & Start sales time of sneakers & The 35th day & The 36th day & The 36th day & The 34th day \\
\hline \multirow{2}{*}{ Middle East-US } & Bulk freight & 0 tons & 17184 tons & 0 tons & 0 tons \\
\hline & Container freight & 0 tons & 0 tons & 0 tons & 0 tons \\
\hline \multirow{2}{*}{ US-China } & Bulk freight & 0 tons & 0 tons & 0 tons & 0 tons \\
\hline & Container freight & 4950 tons & 0 tons & 0 tons & 0 tons \\
\hline \multirow{2}{*}{ Middle East-China } & Bulk freight & 25776 tons & 5728 tons & 5728 tons & 0 tons \\
\hline & Container freight & 330 tons & 334 tons & 334 tons & 1404 tons \\
\hline
\end{tabular}

to prepare the corresponding mold. It seems that the simplification of the process reduces the response time and improves the flow velocity. Although the printing speed of a single printer was still slower than that of the conventional process, some enterprises began to solve the problem. For example, Voodoo Manufacturing Company set up a printer group called Project Skywalker. They designed software to connect several to hundreds of ordinary FDM printers and even mechanical arms or other automation equipment together, just like "robot factory." These 3DP systems or groups could print large numbers of individual components and achieve mass production while maintaining the technical advantages of 3DP (3ders.org) [20]. The same way, of course, can also be applied to athletic footwear manufacturing. Moreover, with the application of CLIP or later the introduction of new technologies, the printing speed of sneakers can fully meet the requirements of mass production. Therefore, the shortcoming of 3DP speed will not delay start sales time any more.

However, the flow velocities of all regions do not become faster after 3DP application. Comparing the start sales time of US and the Middle East, it can be found that when US acts as a resource and consumer country at the same time, namely, Scenario 2 and Scenario 3, its supply chain length is significantly shortened. If all goes well, the time spent of materials flow from oil field to distribution center will take only 15 days at the shortest. In all the scenarios the Middle East plays the role of resource and consumer country. But only in Scenario 3 does it have the ability to produce printing filaments; its start sales time is obviously ahead of schedule. This shows that the production location of 3DP filaments is an 
important factor in the optimization of supply chain length. When the resource country can produce filaments, the supply chain will be significantly shortened. The reduction of related opportunity cost will benefit the further promotion of 3DP in manufacturing. China is not the resource country. Even if it is able to produce filaments, the start sales time of sneakers in China is similar, no matter before or after 3DP.

5.3. Flow Volume. According to Table 10, the 3DP application will reduce about $10 \%$ of the total demand of crude oil. Moreover, in Scenario 2 and Scenario 3, crude flows more in the interior of the resource country. That has resulted in the rapid decrease in oil trade across the oceans. The specialized crude tankers and port facilities will exceed supply. Corresponding in some regions, the demand of pipeline infrastructure for oil land transportation will increase. When concerning new investment plans, the decision makers should consider the impact of 3DP on crude oil logistics.

For container transportation, in any scenario, the simplification of procedures and the self-sufficiency of the resource countries have greatly reduced the overall use of containers in the producer countries, such as China. This has led to a large surplus of container handling facilities in it. In Scenario 3 , the containers in the route China-Middle East no longer carry China's sneakers to the Middle East, but the filaments from the latter to the former. Moreover, the container freight volume in this route has greatly increased compared with other scenes, for China's sales more than the Middle East's. This shows that $3 \mathrm{DP}$ can promote the container use in the export business of resource, which were originally exported in bulk. On the other hand, nowadays China is showing more characteristic of consumer country while this country's per capita income is growing. Its demand of import filaments will keep China's container business at a certain level.

To sum up, taking sneakers supply chain as an example, the application of 3DP will have a serious impact on the global industrial division of labor. On the whole, the demand for cross-border transport will be significantly reduced. In contrast of international crude transportation and container transportation, 3DP has a more negative impact on the former. For the latter, the cargo suitable for container can be changed from sneakers to printing filaments. The total demand of container call still maintains a certain level, but the flow direction changes. Relatively speaking, producer country suffers the greatest shock. And the container business of consumer country and resource country can get better development. When a country has the role of both resource and consumer, the material is transferred within its own territory. Because of no needs for trans-ocean transportation, the utilization of containers will be reduced.

\section{3DP Impact on the Container Hub Port}

The possible impact of 3DP on the sneaker supply chain is discussed in the previous section. But the current 3DP products account for a very low proportion of global cargo flow. In the short term, it is virtually impossible to subvert the global industrial structure. The incumbent container multimodal transport system is still robust. But in the long run, more and more goods will be manufactured by 3DP. Can the case of sneakers be used for reference by other cargo categories? Will they change in the same phase? When producer country suffers the great impact of 3DP, the changing trend of its container hub port can be used to analyze the system, thus inferring the complete process of its evolution, for hub port is the core node of the whole system.

6.1. Object of Study. This section chooses one typical container hub port of the Pearl River Delta area as the object of study. The Pearl River Delta is one of China's major industry clusters. That has led to its huge international cargo throughput. China currently has 7 container ports in the world's largest 10, of which 3 are located in the Pearl River Delta region. In this part Guangzhou port is chosen, for it is the central city of this area. The famous China Import and Export Fair have been held twice per year in Guangzhou since 1957. The characteristics of the main cargo throughput in Guangzhou port can represent the situation of China's foreign trade commodities to some extent. This research first collects the classification statistics of Guangzhou port's import and export goods in recent years, and then discusses which goods are suitable for 3DP mass production in the short or middle term. Finally the container business trend of Guangzhou port after 3DP is predicted.

In order to quantify and compare the characteristics of the various goods in container transport and 3DP, it is necessary to grade their fitness of container transport and probability of 3DP mass production. For the fitness of container transport, the highest type scores 3 , the moderate one scores 2 , and the lowest one scores 1, respectively. For the probability of 3DP mass production, it is the same where the highest type scores 3 , the moderate one scores 2 , and the lowest one scores 1 , respectively. The cargo throughput and the container transport fitness data are from the statistics of Guangzhou customs (2016). The probability prediction of 3DP mass production is from the Wohlers Report $(2015,2016$, and 2017) and Laplume et al. (2016). According to Laplume et al. (2016), raw materials and semichemical products, such as crude, ore, and resins, were generated by other industrial processes. It is impossible for $3 \mathrm{DP}$ to produce them. Therefore, the probability of 3DP mass production of these goods scores $1[12,21-23]$.

The total score for the type $i$ is $X i$. Its fitness of container transport is Fi. And its probability of 3DP mass production is Pi.

$$
X i=F i * P i .
$$

After calculation, Tables 12 and 13 are established, sorted by freight volume from height to low. The former is of the export goods, and the latter is of the import goods.

The higher the total score, the higher the containerization level of the goods, and the greater the possibility of 3DP mass production. For the goods of the same score, when they are manufactured by $3 \mathrm{DP}$ on a large scale, their relevant container business is more vulnerable. In other words, they are in the similar phase of 3DP development. The evolution of their container traffic should be similar too. Then group the goods of the same score into a class to calculate their proportion of the total throughput. For the cargoes which 
TABLE 12: Containerization and 3DP score of major export goods of Guangzhou port.

\begin{tabular}{|c|c|c|c|c|c|c|}
\hline Number & Category of goods & $\begin{array}{l}\text { Freight volume } \\
\text { (tons) }\end{array}$ & $\begin{array}{c}\text { Ratio of international } \\
\text { goods throughput }\end{array}$ & $\begin{array}{l}\text { Fitness of container } \\
\text { transport }(F i)\end{array}$ & $\begin{array}{c}\text { Probability of } 3 \mathrm{DP} \\
\text { mass production }(P i)\end{array}$ & $\begin{array}{l}\text { Total score } \\
\quad(X i)\end{array}$ \\
\hline (1) & $\begin{array}{l}\text { Electrical and electronic } \\
\text { product }\end{array}$ & 46730527.370 & $36.962 \%$ & 3 & 2 & 6 \\
\hline (2) & Wearing apparel & 2042835.393 & $1.616 \%$ & 3 & 3 & 9 \\
\hline (3) & Metal semiproduct & 1537353.479 & $1.216 \%$ & 2 & 2 & 4 \\
\hline (4) & Construction material & 1504129.317 & $1.190 \%$ & 3 & 3 & 9 \\
\hline (5) & Oil and gas & 1360166.590 & $1.076 \%$ & 1 & 1 & 1 \\
\hline (6) & Textiles (ex apparel) & 1266743.068 & $1.002 \%$ & 3 & 3 & 9 \\
\hline (7) & Instrumentation & 933520.837 & $0.738 \%$ & 3 & 2 & 6 \\
\hline (8) & Metal product & 742846.651 & $0.588 \%$ & 3 & 3 & 9 \\
\hline (9) & Mechanical equipment & 660896.916 & $0.523 \%$ & 2 & 2 & 4 \\
\hline (10) & $\begin{array}{l}\text { Other mechanical and } \\
\text { electrical products }\end{array}$ & 512008.203 & $0.405 \%$ & 3 & 2 & 6 \\
\hline (11) & $\begin{array}{l}\text { Luggage, suitcase, and } \\
\text { sports goods }\end{array}$ & 377554.366 & $0.299 \%$ & 3 & 3 & 9 \\
\hline (12) & Agricultural and food & 369267.472 & $0.292 \%$ & 2 & 2 & 4 \\
\hline (13) & Conveyance & 341050.774 & $0.270 \%$ & 2 & 2 & 4 \\
\hline (14) & Other plastic products & 339899.784 & $0.269 \%$ & 3 & 3 & 9 \\
\hline (15) & Toy & 313910.193 & $0.248 \%$ & 3 & 3 & 9 \\
\hline (16) & Footwear & 162196.734 & $0.128 \%$ & 3 & 3 & 9 \\
\hline (17) & Cleaning product & 148585.990 & $0.118 \%$ & 3 & 2 & 6 \\
\hline (18) & Plastic semiproduct & 113924.027 & $0.090 \%$ & 3 & 1 & 3 \\
\hline (19) & Medicine and cosmetic & 49990.431 & $0.040 \%$ & 3 & 2 & 6 \\
\hline (20) & Nonmetallic mineral & 43832.317 & $0.035 \%$ & 1 & 1 & 1 \\
\hline (21) & Paper product & 23207.723 & $0.018 \%$ & 3 & 3 & 9 \\
\hline (22) & Chemical product & 13691.439 & $0.011 \%$ & 2 & 1 & 2 \\
\hline (23) & Wooden product & 10797.701 & $0.009 \%$ & 3 & 3 & 9 \\
\hline (24) & Fertilizer & 5251.158 & $0.004 \%$ & 2 & 1 & 2 \\
\hline (25) & Metallic mineral & 2981.549 & $0.002 \%$ & 1 & 1 & 1 \\
\hline (26) & Jewelry and accessory & 918.885 & $0.001 \%$ & 3 & 3 & 9 \\
\hline
\end{tabular}

are unsuitable for 3DP, that is, their probability of 3DP mass production scores 1 , they are all into a class. The goods in this class will maintain the traditional logistics mode after the large scale application of 3DP. According to the above division, Tables 14 and 15 are established. The former is of the export goods, and the latter is of the import goods.

\subsection{DP Impact Analysis}

6.2.1. Impact on Cargo of Different Classes. Sneaker belongs to the category of foot wear, which scores 9 and in class 1 . The cargo of class 1 accounts for only about $7 \%$ of the total freight throughput, of which $5.368 \%$ is export and $1.963 \%$ is import. This means that even if $3 \mathrm{DP}$ is to a certain degree of large scale application, in the short term there will not be too much cargo similar to the evolution trend of sneaker supply chain. The prediction of 3DP causing manufacturing flow back to Europe and US will not come true for quite a long time. The existing container multimodal transport system will still operate in accordance with established patterns.
But a detailed analysis of the import and export data of Guangzhou port shows that the transportation of electrical and electronic products is very large. Its total ratio is about $55 \%$, including $36.962 \%$ of exports and $18.243 \%$ of imports. This shows that, in the electrical era, the largest contribution to the international container system is not the basic life necessaries, such as clothes and foods, but the electronic products which could bring convenience and enjoyment to people. On the export side, China is already the world's largest exporter of electronic products. On the import side, thanks to China's economic development and the policy to stimulate transnational E-commerce, local consumers' demands for foreign electronic products continue to rise. A large proportion of these products enter Mainland China through the Guangzhou port, where main components are plastic housing, metal parts, and printed circuit boards (PCB). Some of them are also equipped with liquid crystal elements. In accordance with the current technological development, excluding the plastic parts, the remaining components are difficult to be manufactured by 3DP. Another factor which 
TABLE 13: Containerization and 3DP score of major import goods of Guangzhou port.

\begin{tabular}{|c|c|c|c|c|c|c|}
\hline Number & Category of goods & $\begin{array}{c}\begin{array}{c}\text { Freight volume } \\
\text { (tons) }\end{array} \\
\end{array}$ & $\begin{array}{c}\text { Ratio of international } \\
\text { goods throughput }\end{array}$ & $\begin{array}{l}\text { Fitness of container } \\
\text { transport }(F i)\end{array}$ & $\begin{array}{c}\text { Probability of 3DP } \\
\text { mass production }(\mathrm{Pi})\end{array}$ & $\begin{array}{c}\text { Total score } \\
(X i)\end{array}$ \\
\hline (1) & $\begin{array}{l}\text { Electrical and electronic } \\
\text { product }\end{array}$ & 23064364.250 & $18.243 \%$ & 3 & 2 & 6 \\
\hline (2) & Coal & 15235465.660 & $12.051 \%$ & 1 & 1 & 1 \\
\hline (3) & Agricultural and food & 7356585.459 & $5.819 \%$ & 2 & 2 & 4 \\
\hline (4) & Metallic mineral & 5002291.483 & $3.957 \%$ & 1 & 1 & 1 \\
\hline (5) & Plastic semiproduct & 2555210.770 & $2.021 \%$ & 3 & 1 & 3 \\
\hline (6) & Metal semiproduct & 2045193.182 & $1.618 \%$ & 2 & 2 & 4 \\
\hline (7) & Oil and gas & 1188932.120 & $0.940 \%$ & 1 & 1 & 1 \\
\hline (8) & Wooden product & 1105243.984 & $0.874 \%$ & 3 & 3 & 9 \\
\hline (9) & Paper product & 856372.732 & $0.677 \%$ & 3 & 3 & 9 \\
\hline (10) & Textiles (ex apparel) & 423746.435 & $0.335 \%$ & 3 & 3 & 9 \\
\hline (11) & Chemical product & 274391.155 & $0.217 \%$ & 2 & 1 & 2 \\
\hline (12) & Pulp & 252793.144 & $0.200 \%$ & 2 & 1 & 2 \\
\hline (13) & Mechanical equipment & 184964.670 & $0.146 \%$ & 2 & 2 & 4 \\
\hline (14) & Instrumentation & 169461.872 & $0.134 \%$ & 3 & 2 & 6 \\
\hline (15) & Conveyance & 146262.425 & $0.116 \%$ & 2 & 2 & 4 \\
\hline (16) & Metal product & 80137.177 & $0.063 \%$ & 3 & 3 & 9 \\
\hline (17) & Dye and paint & 38095.114 & $0.030 \%$ & 3 & 1 & 3 \\
\hline (18) & Fiber material & 27194.573 & $0.022 \%$ & 2 & 1 & 2 \\
\hline (19) & $\begin{array}{l}\text { Other mechanical and } \\
\text { electrical products }\end{array}$ & 21035.204 & $0.017 \%$ & 3 & 2 & 6 \\
\hline (20) & Other plastic products & 17502.981 & $0.014 \%$ & 3 & 3 & 9 \\
\hline (21) & Medicine and cosmetic & 10884.571 & $0.009 \%$ & 3 & 2 & 6 \\
\hline$(22)$ & Fertilizer & 884.310 & $0.001 \%$ & 2 & 1 & 2 \\
\hline
\end{tabular}

cannot be ignored is that, after the parts are printed out, there is a certain process to assemble them together. It is troublesome for consumers to complete the assembly manually. So it seems unlikely that the 3DP of electrical appliances will be popular in the short term.

But today several teams are working to overcome the problem involved. For example, some laboratories have made preliminary achievements in the 3DP of PCB through the development of conductive materials (3ders.org) [24, 25]. There are teams also working hard in cheap printing of metal parts (3Dprint.com) [26] (All3dp.com) [27]. Making a product composed of a variety of materials is difficult to accomplish with just one printer, while one short board of the existing 3DP is that the same type of printer is only limited to specific materials. But now Stratasys and other companies have designed multihead-printer to print several different materials at the same workflow. As for assembly problems, this can be solved by the characteristics of 3DP. This additive manufacturing technology can generate complex geometry structure. Through effective industrial design, some structures can be printed directly without the need for embedding or riveting, which will reduce considerably assembly activities. In other words, although not as quick as the goods of class 1 , the electronic products will achieve 3DP mass production in the medium term, maybe 10 to 15 years. It belongs to class 2 . The proportion of the class 2 cargo is about $57 \%$, including $38.263 \%$ of exports and $18.403 \%$ of imports. If the goods of this class can be mass-produced by 3DP, the story of the sneaker supply chain will take place. Its impact on the circulation mode of goods in Guangzhou port is quite large. The relevant parties of the container logistics system should pay close attention to this and make appropriate countermeasures in advance.

The goods of class 3 mainly include agricultural products, metal semiproducts, mechanical equipment, and conveyance. Because of the biological properties and seasonal requirements, agricultural products are not so suitable for 3DP, except for a few foods which require more in appearance than taste. As for other industrial products, due to the size, assembly procedure, and other reasons, they are difficult to produce in small distributed printers. So their manufacture is still centralized. In the maintenance of this kind of goods, there is a certain demand for 3DP spare parts. But their total amount is not large. Therefore, the change of the goods in this class has little effect on the existing container transport system.

The goods of class 4 are the raw materials and semiproducts which 3DP is unable to print. Their imports are much higher than that of exports. This conforms to the characteristics of cargo composition in the producer country. When 3DP is widely used in the manufacture of the goods of class 2 , the export manufacturing activities of China will gradually move to consumer countries. At this time, China has not so much 
TABLE 14: Containerization and 3DP classification of major export goods of Guangzhou port.

\begin{tabular}{|c|c|c|c|c|c|}
\hline Number & Category of goods & $\begin{array}{c}\text { Ratio of international } \\
\text { goods throughput }\end{array}$ & Total score & Class & $\begin{array}{c}\text { Ratio of throughput in } \\
\text { this level }\end{array}$ \\
\hline (2) & Wearing apparel & $1.616 \%$ & 9 & \multirow{11}{*}{1} & \multirow{11}{*}{$5.368 \%$} \\
\hline (4) & Construction material & $1.190 \%$ & 9 & & \\
\hline (6) & Textiles (ex apparel) & $1.002 \%$ & 9 & & \\
\hline (8) & Metal product & $0.588 \%$ & 9 & & \\
\hline (11) & Luggage, suitcase, and sports goods & $0.299 \%$ & 9 & & \\
\hline (14) & Other plastic products & $0.269 \%$ & 9 & & \\
\hline (15) & Toy & $0.248 \%$ & 9 & & \\
\hline (16) & Footwear & $0.128 \%$ & 9 & & \\
\hline$(21)$ & Paper product & $0.018 \%$ & 9 & & \\
\hline$(23)$ & Wooden product & $0.009 \%$ & 9 & & \\
\hline$(26)$ & Jewelry and accessory & $0.001 \%$ & 9 & & \\
\hline (1) & Electrical and electronic product & $36.962 \%$ & 6 & \multirow{5}{*}{2} & \multirow{5}{*}{$38.263 \%$} \\
\hline (7) & Instrumentation & $0.738 \%$ & 6 & & \\
\hline (10) & Other mechanical and electrical products & $0.405 \%$ & 6 & & \\
\hline (17) & Cleaning product & $0.118 \%$ & 6 & & \\
\hline (19) & Medicine and cosmetic & $0.040 \%$ & 6 & & \\
\hline (3) & Metal semiproduct & $1.216 \%$ & 4 & \multirow{4}{*}{3} & \multirow{4}{*}{$2.301 \%$} \\
\hline (9) & Mechanical equipment & $0.523 \%$ & 4 & & \\
\hline (12) & Agricultural and food & $0.292 \%$ & 4 & & \\
\hline (13) & Conveyance & $0.270 \%$ & 4 & & \\
\hline (18) & Plastic semiproduct & $0.090 \%$ & 3 & \multirow{6}{*}{4} & \multirow{6}{*}{$1.218 \%$} \\
\hline (22) & Chemical product & $0.011 \%$ & 2 & & \\
\hline$(24)$ & Fertilizer & $0.004 \%$ & 2 & & \\
\hline (5) & Oil and gas & $1.076 \%$ & 1 & & \\
\hline$(20)$ & Nonmetallic mineral & $0.035 \%$ & 1 & & \\
\hline (25) & Metallic mineral & $0.002 \%$ & 1 & & \\
\hline
\end{tabular}

needs of raw materials to manufacturing international commodities. The import of class 4 goods is mainly for the Chinese local consumers. That is to say, the amount of its import depends on the local consumption capacity. In any case, the change of such goods has very little impact on the container transport system.

6.2.2. Impact on Relevant Routes. The traditional international container liner routes generally included three major parts, Far East-US Western Coast, Europe/MediterraneanUS Eastern Coast, and Far East-Europe/Mediterranean. In recent years, with the deepening of the Panama Canal and the development of the Southern countries, new routes, such as Far East-US Eastern Coast and Far East-South America, have also opened up. Guangzhou port is an important node in the Far East. As of September 2017, the world's top 20 liner companies were operating at this port. It had 163 container routes, covering Europe, Americas, Africa, Asia, and other major ports in the worldwide range. COSCO, China Shipping, and other Chinese companies treated Guangzhou port as the base and opened the coastal routes from it to other domestic ports. Guangzhou has become the largest distribution center and conversion hub in the Southern China. Therefore, the phased impact of 3DP on this port will inevitably be transmitted through these routes and then affect the whole world.

According to Tables 14 and 15, the port's exports and imports were approximately the same. But analyzing in depth, their ratios were not the same at different class. So the $3 \mathrm{DP}$ impacts on them would be different. Take the cargo class as the horizontal axis and the ratio of the import and export as the vertical axis to determine Figure 5. As shown in Figure 5, whether it is Class 1 or Class 2, exports are significantly more than imports. According to the analysis of the Section 6.1, the goods of Class 1 are firstly affected by 3DP, then Class 2, and then Class 3, while Class 4 is less affected. This means that from the Class 1 phase to the Class 2 phase, the evolution like the sneaker supply chain will occur in more export goods. With the gradual development of 3DP and the outflow of manufacturing activities, the structure of import and export will be reversed while the total throughput is shrinking. Most of the declined volume comes from exports, not imports. Container operators will configure the capacity of the relevant routes based on this trend. As for the shrinking import volume, they are usually transported by bulk carriers and tankers. The impact on containers is relatively low. 
TABLE 15: Containerization and 3DP classification of major import goods of Guangzhou port.

\begin{tabular}{|c|c|c|c|c|c|}
\hline Number & Category of goods & $\begin{array}{l}\text { Ratio of international } \\
\text { goods throughput }\end{array}$ & Total score & Class & $\begin{array}{c}\text { Ratio of throughput in } \\
\text { this level }\end{array}$ \\
\hline (8) & Wooden product & $0.874 \%$ & 9 & \multirow{5}{*}{1} & \multirow{5}{*}{$1.963 \%$} \\
\hline (9) & Paper product & $0.677 \%$ & 9 & & \\
\hline (10) & Textiles (ex apparel) & $0.335 \%$ & 9 & & \\
\hline (16) & Metal product & $0.063 \%$ & 9 & & \\
\hline$(20)$ & Other plastic products & $0.014 \%$ & 9 & & \\
\hline (1) & Electrical and electronic product & $18.243 \%$ & 6 & \multirow{4}{*}{2} & \multirow{4}{*}{$18.403 \%$} \\
\hline (14) & Instrumentation & $0.134 \%$ & 6 & & \\
\hline (19) & Other mechanical and electrical products & $0.017 \%$ & 6 & & \\
\hline$(21)$ & Medicine and cosmetic & $0.009 \%$ & 6 & & \\
\hline (3) & Agricultural and food & $5.819 \%$ & 4 & \multirow{4}{*}{3} & \multirow{4}{*}{$7.699 \%$} \\
\hline (6) & Metal semi product & $1.618 \%$ & 4 & & \\
\hline (13) & Mechanical equipment & $0.146 \%$ & 4 & & \\
\hline$(15)$ & Conveyance & $0.116 \%$ & 4 & & \\
\hline (5) & Plastic semiproduct & $2.021 \%$ & 3 & \multirow{9}{*}{4} & \multirow{9}{*}{$19.439 \%$} \\
\hline (17) & Dye and paint & $0.030 \%$ & 3 & & \\
\hline (11) & Chemical product & $0.217 \%$ & 2 & & \\
\hline (12) & Pulp & $0.200 \%$ & 2 & & \\
\hline (18) & Fiber material & $0.022 \%$ & 2 & & \\
\hline$(22)$ & Fertilizer & $0.001 \%$ & 2 & & \\
\hline (2) & Coal & $12.051 \%$ & 1 & & \\
\hline (4) & Metallic mineral & $3.957 \%$ & 1 & & \\
\hline$(7)$ & Oil and gas & $0.940 \%$ & 1 & & \\
\hline
\end{tabular}

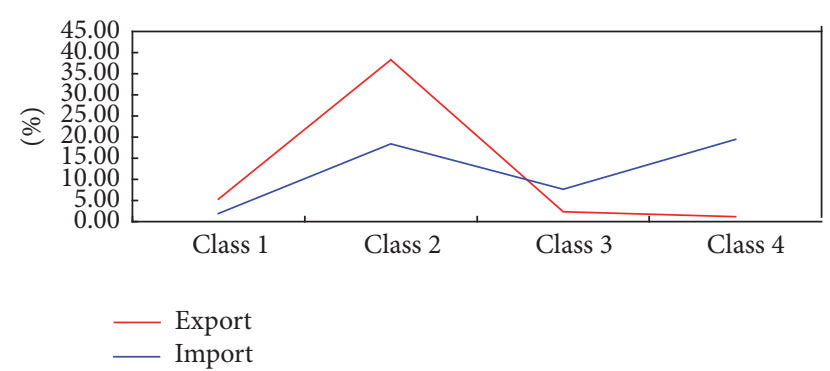

FIGURE 5: Export and import ratios in different classes of Guangzhou port.

Analyzing the export and import countries of Guangzhou port, maybe 3DP will not necessarily affect the container throughput as per the expected progress, for not all international container business acts as "resource country-producer country-consumer country" mode. This research is based on the sneaker supply chain among China, US, and the Middle East. But according to Wohlers Report 2017, an estimated $28.8 \%$ of all industrial 3DP systems installed worldwide were in the Asia/Pacific region. Meanwhile, $27.9 \%$ were in Europe and $38.7 \%$ were in North America. The remaining $4.5 \%$ were in Latin America, the Middle East, and Africa. At present, the relevant technologies were the most in-depth study in
Europe and US, while they have been advocating the reflow of manufacturing based on 3DP. Although Japan, Korea, and China were also putting more resources into 3DP, the overall progress was not as good as the former [23]. Therefore, the most likely subversion may be the trade between China-US and China-Europe. What about other countries and regions?

Tables 16 and 17 were obtained based on Guangzhou customs statistics 2016. As shown in the two tables, European and North America were the main destination for Guangzhou port exports. Even excluding the reexports from Hong Kong SAR, their total share was still about 30\%, with $14.89 \%$ for Europe and $15.62 \%$ for North America. That means the application of 3DP will significantly affect their exports in the short and medium term. But at this phase, the 3DP technologies of China do not exceed the ones of Europe and US. The cargo whose origin is Europe or US cannot be printed well in China yet. The import requirement will still exist and relevant container business will maintain a certain level.

When 3DP technology spread from Europe and US to the Far East or the latter may exceed the former through the advantage of backwardness, the global centralized mode will be completely broken. More than $70 \%$ of the cargo throughput will act just like the evolution of sneaker supply chain, no matter export or import. For imports, the largest importers of Guangzhou were Japan and Korea. Different from the primary material of resource country, Japan and 
TABLE 16: 20 countries and regions with the largest import and export volume in Guangzhou port.

\begin{tabular}{|c|c|c|c|c|c|c|}
\hline Rank & $\begin{array}{c}\text { Countries and regions } \\
\text { with the largest } \\
\text { exports }\end{array}$ & $\begin{array}{l}\text { Export trade } \\
\text { volume } \\
\left(10^{4} \text { dollars }\right) \\
\end{array}$ & $\begin{array}{l}\text { Proportion of total } \\
\text { export trade }\end{array}$ & $\begin{array}{c}\text { Countries and regions } \\
\text { with the largest } \\
\text { imports }\end{array}$ & $\begin{array}{l}\text { Import trade volume } \\
\left(10^{4} \text { dollars }\right)\end{array}$ & $\begin{array}{c}\text { Proportion of } \\
\text { total import } \\
\text { trade } \\
\end{array}$ \\
\hline 1 & Hong Kong SAR & $1,457,077.42$ & $18.536 \%$ & Japan & $930,794.97$ & $18.215 \%$ \\
\hline 2 & US & $1,144,102.53$ & $14.555 \%$ & Korea & $623,476.88$ & $12.201 \%$ \\
\hline 3 & Japan & $345,825.75$ & $4.399 \%$ & US & $552,985.77$ & $10.822 \%$ \\
\hline 4 & India & $224,677.03$ & $2.858 \%$ & South Africa & $275,112.91$ & $5.384 \%$ \\
\hline 5 & Malaysia & $221,200.65$ & $2.814 \%$ & Taiwan, China & $263,365.78$ & $5.154 \%$ \\
\hline 6 & UK & $202,302.46$ & $2.574 \%$ & Germany & $241,677.77$ & $4.730 \%$ \\
\hline 7 & Mexico & $191,302.65$ & $2.434 \%$ & India & $147,073.76$ & $2.878 \%$ \\
\hline 8 & Germany & $186,400.08$ & $2.371 \%$ & Malaysia & $127,035.48$ & $2.486 \%$ \\
\hline 9 & Vietnam & $182,761.88$ & $2.325 \%$ & Thailand & $124,773.63$ & $2.442 \%$ \\
\hline 10 & Korea & $152,973.66$ & $1.946 \%$ & Indonesia & $112,457.75$ & $2.201 \%$ \\
\hline 11 & UAE & $141,567.17$ & $1.801 \%$ & Australia & $101,841.09$ & $1.993 \%$ \\
\hline 12 & Singapore & $137,449.04$ & $1.749 \%$ & France & $100,433.60$ & $1.965 \%$ \\
\hline 13 & Nigeria & $135,350.01$ & $1.722 \%$ & Vietnam & $96,774.91$ & $1.894 \%$ \\
\hline 14 & Thailand & $132,306.75$ & $1.683 \%$ & Netherlands & $89,939.46$ & $1.760 \%$ \\
\hline 15 & Indonesia & $130,854.57$ & $1.665 \%$ & UAE & $86,787.34$ & $1.698 \%$ \\
\hline 16 & Taiwan, China & $126,597.45$ & $1.611 \%$ & Italy & $82,809.35$ & $1.621 \%$ \\
\hline 17 & Saudi Arabia & $125,249.90$ & $1.593 \%$ & Singapore & $75,027.86$ & $1.468 \%$ \\
\hline 18 & Philippines & $122,706.52$ & $1.561 \%$ & Brazil & $62,952.66$ & $1.232 \%$ \\
\hline 19 & Netherlands & $118,423.16$ & $1.507 \%$ & Philippines & $54,007.56$ & $1.057 \%$ \\
\hline 20 & Australia & $117,262.73$ & $1.492 \%$ & Hong Kong SAR & $52,748.18$ & $1.032 \%$ \\
\hline
\end{tabular}

TABLE 17: Continents with the largest import and export volume in Guangzhou port.

\begin{tabular}{|c|c|c|c|c|c|c|}
\hline Rank & $\begin{array}{l}\text { Continents with the } \\
\text { largest exports }\end{array}$ & $\begin{array}{l}\text { Export trade } \\
\text { volume } \\
\left(10^{4} \text { dollars }\right)\end{array}$ & $\begin{array}{l}\text { Proportion of total } \\
\text { export trade }\end{array}$ & $\begin{array}{l}\text { Continents with the } \\
\text { largest imports }\end{array}$ & $\begin{array}{l}\text { Import trade volume } \\
\quad\left(10^{4} \text { dollars }\right)\end{array}$ & $\begin{array}{c}\text { Proportion of } \\
\text { total import } \\
\text { trade }\end{array}$ \\
\hline 1 & Asia-Pacific & $3,269,799.47$ & $41.60 \%$ & Asia-Pacific & 2620400.69 & $51.28 \%$ \\
\hline 2 & North America & $1,228,080.74$ & $15.62 \%$ & Europe & $808,570.14$ & $15.82 \%$ \\
\hline 3 & Europe & $1,170,198.67$ & $14.89 \%$ & North America & $595,338.74$ & $11.65 \%$ \\
\hline 4 & Africa & $844,983.87$ & $10.75 \%$ & Africa & $315,775.44$ & $6.18 \%$ \\
\hline 5 & Middle East & $498,906.26$ & $6.35 \%$ & Middle Asia & $286,013.87$ & $5.60 \%$ \\
\hline 6 & Latin America & $440,747.19$ & $5.61 \%$ & South Asia & $183,097.50$ & $3.58 \%$ \\
\hline 7 & South Asia & $367,005.38$ & $4.67 \%$ & Middle East & $150,693.53$ & $2.95 \%$ \\
\hline 8 & Middle Asia & $40,979.59$ & $0.52 \%$ & Latin America & $149,325.81$ & $2.92 \%$ \\
\hline
\end{tabular}

Korea tended to sell their high-tech components to China, such as the camera and LCD panel for mobile phone and appliances. Chinese foundries assembled these and other parts into finished product and then exported. If 3DP leads to distributed production, these countries can send these components directly to Europe and US and print the final product at the local distribution center. But on the other hand, in recent years, China's technological advances have achieved some components being produced locally. Japan, Korea, and China all belong to the Far East. If such products still cannot be printed well in the consumer countries, the whole Far East will maintain their exports.

But even in the whole Asia, only China, India, Japan, Korea, and Singapore have achieved remarkable results in the research and development of 3DP (Wohlers Reports 2017) [23]. Other regions, including ASEAN, Central Asia, and most of the Middle East, were still not paying enough attention to it. Coupled with the trade volume with Latin America and Africa, the container business between Guangzhou port and developing countries should not be affected by 3DP for a long time. It will be still dominated by traditional mode.

Different from 3DP which leads to distributed production, the "Belt and Road" initiative launched by China is regarded as another important factor that may impact the existing international industrial division, but with the opposite direction. The initiative included a series of measures to boost international trade and globalization, such as funding support, industrial transfer, and infrastructure construction. 
It has been welcomed by regions such as ASEAN, Central Asia, and Africa. Guangzhou port was an important hub among China and these countries to strengthen ties with each other. When they improve their container infrastructure, Guangzhou port container business with them may be further improved (Wang et al., 2017) [28]. This means that the container business reduction of developed countries will be covered by that of the above developing countries.

\section{Conclusion}

The application of container multimodal transport system can standardize the process of international logistics, reduce the time and risk of trans-continental transportation, and significantly cut down the cost of global commodity flow. Its prosperity is an important promoter of postwar globalization. But as consumer tastes improve, their choice of commodities not only is based on price factors, but also emphasizes personalization and quick acquisition. In the meantime, the severe global economic situation makes the trade protectionism, some governments in consumer countries introduced a number of measures to encourage manufacturing backflow, and some of the commodity production was gradually transferring to the end of supply chain. Global manufacturing activities are changing from centralized to distributed one. This has promoted the rapid development of 3DP and other digital manufacturing technology in recent years. Will the incumbent globalization process be interrupted? Will the existing industrial pattern collapse? Will this have a serious impact on the container logistics system? This is the starting point of this research.

7.1. 3DP Impact on Transnational Container Logistics Business. In the first step of the derivation, this research begins with a case study of 3DP sneakers. The model of transnational supply chain is established using system dynamics, and the different characteristics of the material flow under three possible evolution scenarios are investigated. Simulation results show that the application of 3DP will make the global industrial division of "resource-producer-consumer" suffere a severe shock. The supply chain will change significantly in three aspects: flow direction, flow velocity, and flow volume. In either case, the aggregate demand for international transport will be significantly reduced. For different stages of the chain, the bulk transportation of crude is more negatively affected by 3DP than the container transportation of semiproducts and final products. The reason is that the shipment object of container can change from sneakers to printing filaments, and its total volume can still maintain a certain level.

However, how much cargo suitable for container will be replaced from the finished products to the printing filaments? It needs further investigation. That is because an important uncertainty is recycled printing material. After the 3DP products are abandoned, some of them can be handled properly for recycling. This may greatly reduce the demand of new filament. In the conventional process, the recycling of plastic waste was the responsibility of a professional company, which requires proper qualification and a lot of upfront investment. And the scale of garbage collection is needed to meet certain standards. But 3DP allows consumers themselves to become qualified environmentalists. Initially, large 3DP enterprises were not willing to develop the recycled business, for the quality requirement and profit pursuit of industrial level filaments. The recycled materials were developed more by some start-up companies (Treehugger.com) [29]. However, with the deterioration of the earth's environment, the young consumers, who were called the Generation $Y$ and the main supporters of 3DP products, had changed their consumption concept greatly (Gurtner \& Soyez, 2016) [30]. They would choose more environmental-friendly products (Kreiger et al. 2014) [31]. This would also promote professional companies to develop related recycling processes at industrial level. For example, 3D Systems Company has designed a 3D printer called EKOCYCLE Cube which uses recycled plastic filaments (3Dsystems.com) [32]. The extent of distributed production will be further enhanced if more large enterprises participate in this business. By then, end-consumers may tend to use local recycled filaments instead of newly made ones from overseas. That will once again reduce the international container demand. As a result, consumer perception of environmental protection is an unknown variable affecting container operations in the 3DP era. The relevant data needs to be collected continuously for more accurate forecasts.

7.2. 3DP Impact on Global Container Multimodal System. Will the trend of the sneaker supply chain happen in other goods? How to infer the complete evolution process of global container logistics system through the changes of various supply chain? In the second step of the derivation, this research establishes a comprehensive index system based on the international throughput data of Guangzhou port and the modern 3DP documents. The evaluations suggest that, according to current trends of 3DP, in the short term only about $7 \%$ of the cargo throughput will change like the sneakers supply chain. This will not have a significant impact on the container system. However, when the 3DP mass production of electrical products has come true, about $60 \%$ of the cargo will undergo obvious variation. The characteristics of cargo handling in Guangzhou port are typical in China. This means that China's role as a producer of the global industry will be subverted.

3DP mass production of electrical products will be the break sign of the incumbent global industrial pattern. By then, more products will be transferred from centralized production to distributed production. However, the return of manufacturing from producer countries to consumer countries may not happen immediately. 3DP reduces the advantage of labor cost of producer countries but raises the importance of raw materials of resource countries. While several resource countries are also committed to 3DP research and development, in the premise to achieve the necessary technical ability, part of the manufacturing activities may be diverted to these regions. In this research, crude oil is used as the main resource. But in fact, resources such as minerals and agricultural products are also the main components of international raw materials. If all the countries use their own natural resource advantages to strengthen the trade of $3 \mathrm{DP}$ materials, even if the bulk cargo's trans-ocean transportation 
is reduced, the service objects of containers will be converted from finished products to 3DP materials. This allows the container multimodal transport system to continue running at a certain level, within its flow direction, velocity, and volume changing.

For different countries, 3DP has different impact. The producer country is shocked the most. Without the own demand of the local consumers, the outflow of manufacturing activities will significantly reduce its container business. At the same time, the inflow of manufacturing has led to a certain increase in volume of container traffic in consumer country. But the impact on the resource country is twofold. Its crude oil exports will decline, while its container business is likely to grow. This is because the relevant container demand will be greatly stimulated when the export goods change from crude to filaments. On the other hand, when a country has both roles of resource and consumer countries, the selfsufficient supply chain makes the production and marketing happen domestically. The demand for multimodal transportation has decreased significantly. More pure land transport will prevail. As container is more suitable for the former, the container trailer may be replaced by ordinary freight truck. This will also reduce the utilization of containers.

The above discussion has assumed that the resource countries are able to master the key 3DP technologies to achieve self-sufficiency in the finished product. But the analysis of Guangzhou port shows that the impact of 3DP is not immediate and comprehensive. It has different impacts on international goods of various class and countries. As far as crude oil is concerned, US can play the role of resource and consumer countries at the same time. So the manufacturing activities of Class 1 and Class 2 will gradually flow back to this country. But most of Europe is not resource countries. Although some European countries are leading in frontier 3DP technology, its large scale application in Europe is constrained by filament resource. Even taking into account the use of recycled materials, the container business between Europe and resource country still needs to maintain a certain level to meet the needs of local consumers. For traditional oil producing regions, the Middle East, Africa, and South America, while Dubai, UAE, is ambitious to become a regional 3DP hub, the rest of the countries seem not to know the appropriate technology well. Moreover, many resource countries belong to the type of a large population but low income. Although 3DP demand in these places may exist, its relatively high prices will make these countries for a long time not become the mainstream areas of this technology. Their industrial mode tends to be traditional. On the other hand, when the producer country is faced with the deglobalization which is the result of 3DP application and trade protectionism, it may actively respond with measures to maintain consistency of the process of globalization, such as Belt and Road initiative proposed by China. Moreover, producer country had a lot of opportunities to contact with the advanced production frontier. It could be easier to grasp relevant technologies for their own use, such as Chinese innovation policy spawning many 3DP research teams in recent years (Chen, 2015) [33]. In other words, when the mass application of 3DP realizes, the future container business for US will be reduced obviously and then Europe's.
But freight traffic in other regions may remain unchanged or even rise to cover the share of the former. Technology development and trade cooperation will work together in this container system to make more and more dynamic changes.

\section{Conflicts of Interest}

The author declares that there are no conflicts of interest regarding the publication of this paper.

\section{Acknowledgments}

This research is supported by Foundation for Distinguished Young Talents in Higher Education of Guangdong, China (2015WQNCX088), and Zhanjiang Science and Technology Planning Project (2016A01030).

\section{References}

[1] M. Levinson, The Box: How the Shipping Container Made the World Smaller and the World Economy Bigger, Princeton University Press, 2008.

[2] C. Weller, R. Kleer, and F. T. Piller, "Economic implications of 3D printing: market structure models in light of additive manufacturing revisited," International Journal of Production Economics, vol. 164, pp. 43-56, 2015.

[3] J. M. Tien, "Manufacturing and services: From mass production to mass customization," Journal of Systems Science and Systems Engineering, vol. 20, no. 2, pp. 129-154, 2011.

[4] B. Berman, "3-D printing: The new industrial revolution," Business Horizons, vol. 55, no. 2, pp. 155-162, 2012.

[5] M. Zeleny, "High technology and barriers to innovation: from globalization to relocalization," International Journal of Information Technology \& Decision Making, vol. 11, no. 2, pp. 441456, 2012.

[6] A. Scott and T. P. Harrison, "Additive Manufacturing in an End-to-End Supply Chain Setting," 3D Printing and Additive Manufacturing, vol. 2, no. 2, pp. 65-77, 2015.

[7] S. H. Khajavi, J. Partanen, J. Holmström, and J. Tuomi, "Risk reduction in new product launch: a hybrid approach combining direct digital and tool-based manufacturing," Computers in Industry, vol. 74, pp. 29-42, 2015.

[8] M. Ruffo, C. Tuck, and R. Hague, "Make or buy analysis for rapid manufacturing," Rapid Prototyping Journal, vol. 13, no. 1, pp. 2329, 2007.

[9] I. Sirichakwal and B. Conner, "Implications of additive manufacturing for spare parts inventory," $3 D$ Printing and Additive Manufacturing, vol. 3, no. 1, pp. 56-63, 2016.

[10] C. Cautela, P. Pisano, and M. Pironti, "The emergence of new networked business models from technology innovation: an analysis of 3-D printing design enterprises," International Entrepreneurship and Management Journal, vol. 10, no. 3, pp. 487-501, 2014.

[11] B. T. Wittbrodt, A. G. Glover, J. Laureto et al., "Life-cycle economic analysis of distributed manufacturing with open-source 3D printers," Mechatronics, vol. 23, no. 6, pp. 713-726, 2013.

[12] A. O. Laplume, B. Petersen, and J. M. Pearce, "Global value chains from a 3D printing perspective," Journal of International Business Studies, vol. 47, no. 5, pp. 595-609, 2016.

[13] D. R. Gress and R. V. Kalafsky, "Geographies of production in 3D: Theoretical and research implications stemming from additive manufacturing," Geoforum, vol. 60, pp. 43-52, 2015. 
[14] Z. Chen, "Research on the impact of 3D printing on the international supply chain," Advances in Materials Science and Engineering, vol. 2016, Article ID 4173873, 16 pages, 2016.

[15] X. Dong, Y. Jin, and T. Li, "The effect of 3D printing technology on logistics enterprises storage based on the case of UPS," Science and Technology Management Research, vol. 144, no. 13, pp. 106-109, 2016 (Chinese).

[16] J. Vincent, "Adidas reveals the first 3D-printed shoe it'll massproduce," in The Verge, 2017, https://www.theverge.com/2017/ 4/7/15216724/adidas-3d-printed-sneaker-futurecraft.

[17] M. Bogers, R. Hadar, and A. Bilberg, "Additive manufacturing for consumer-centric business models: Implications for supply chains in consumer goods manufacturing," Technological Forecasting \& Social Change, vol. 102, pp. 225-239, 2016.

[18] S. E. Zeltmann, N. Gupta, N. G. Tsoutsos, M. Maniatakos, J. Rajendran, and R. Karri, "Manufacturing and Security Challenges in 3D Printing," JOM: The Journal of The Minerals, Metals \& Materials Society (TMS), vol. 68, no. 7, pp. 1872-1881, 2016.

[19] "3D printing materials market: Middle East industry analysis and opportunity assessment, 2015-2025," Future Market Insight Report, 2016.

[20] Benedict, "Voodoo Manufacturing's new 'Project Skywalker' links NINE 3D printers and a robotic arm," 3ders.org, 2017, http://www.3ders.org/articles/20170315-voodoo-manufacturings-new-project-skywalker-links-nine-3d-printers-and-a-robotic-arm.html.

[21] T. Wohlers and T. Caffrey, "Additive manufacturing and 3D printing state of the industry: annual worldwide progress report," Wohlers report 2015, Wohlers, Fort Collins, CO, USA, 2015.

[22] T. Wohlers and T. Caffrey, "Additive manufacturing and 3D printing state of the industry: annual worldwide progress report," Wohlers report 2016, Wohlers, Fort Collins, CO, USA, 2016.

[23] T. Wohlers and T. Caffrey, "Additive manufacturing and 3D printing state of the industry: annual worldwide progress report," Tech. Rep., Wohlers, Fort Collins, CO, USA, 2017.

[24] Benedict, "Nano Dimension supplies first DragonFly 2020 PCB 3D printer to Israeli defense company, posts Q2 financial results," 3ders.org, 2016, http://www.3ders.org/articles/ 20160825-nano-dimension-supplies-first-dragonfly-2020-pcb3d-printer-to-israeli-defense-company-posts-q2-financial-results .html.

[25] Benedict, "Guiseppe Finizia’s popular 3D printed PCB workstation gets 'crane arms' update," 3ders.org, 2017, http://www .3ders.org/articles/20170220-giuseppe-finizias-popular-3d-printedpcb-workstation-gets-crane-arms-update.html.

[26] E. Krassenstein, "Engineer creates a unique 3D metal printer for just \# - Prints in gold, platinum, iron \& more," 3D print.com, 2015, https://3dprint.com/47065/argentinian-3d-metal-printer.

[27] A. Locker, "Metal 3D printer guide 2017 - all about metal 3D printing," All3dp.com, 2017, https://all3dp.com/metal-3d-printerguide.

[28] F. Wang, J. J. Huang, and Z. Y. Liu, "Port management and operations: Emerging research topics and progress," Journal of Management Sciences in China, vol. 20, no. 5, pp. 111-126, 2017.

[29] M. Treacy, "Recycled plastic filament for 3D printers is here," Treehugger.com, 2015, https://www.treehugger.com/gadgets/ recycled-3d-printer-filament.html.

[30] S. Gurtner and K. Soyez, "How to catch the generation Y: Identifying consumers of ecological innovations among youngsters,"
Technological Forecasting \& Social Change, vol. 106, pp. 101-107, 2016.

[31] M. A. Kreiger, M. L. Mulder, A. G. Glover, and J. M. Pearce, "Life cycle analysis of distributed recycling of post-consumer high density polyethylene for 3-D printing filament," Journal of Cleaner Production, vol. 70, pp. 90-96, 2014.

[32] "What is EKOCYCLE Cube 3D printer?" 3Dsystems.com, 2015, https://www.3dsystems.com/shop/support/ekocycle/faq?redirectFrom $=$ cubify.

[33] Z. Chen, "Research on the interaction between innovation and port-city economic system: a case from China," Discrete Dynamics in Nature and Society, vol. 2015, Article ID 692476, 9 pages, 2015. 


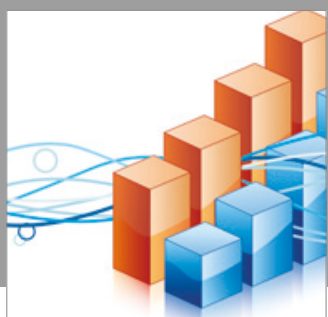

Advances in

Operations Research

vatersals

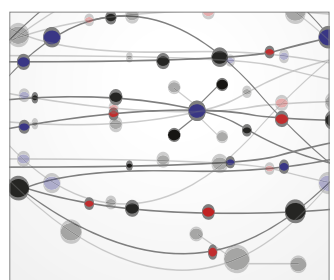

\section{The Scientific} World Journal
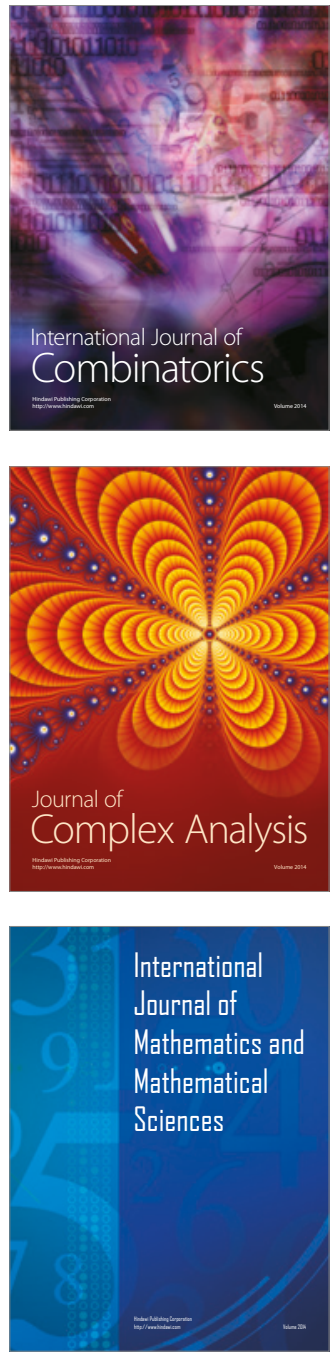
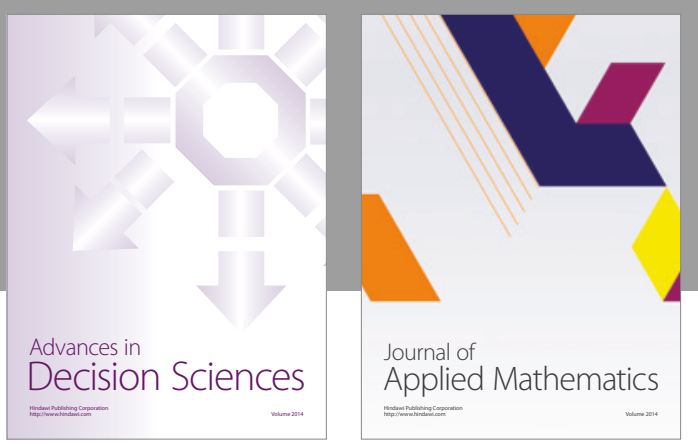

Algebra

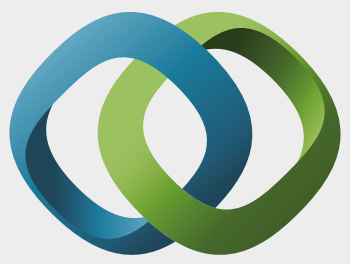

\section{Hindawi}

Submit your manuscripts at

https://www.hindawi.com
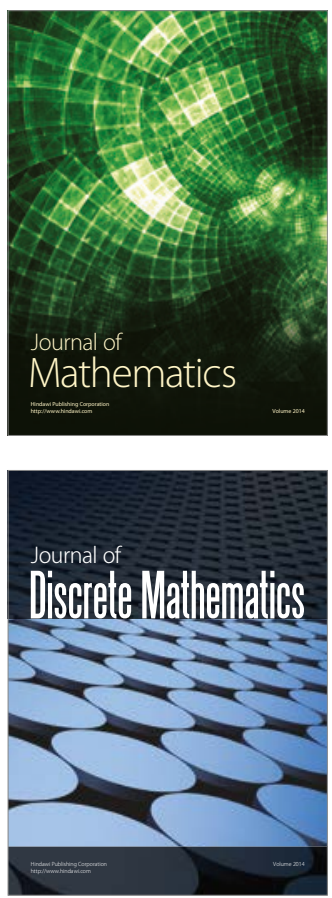

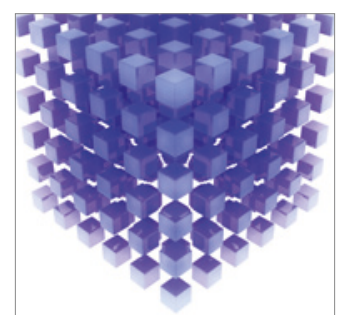

Mathematical Problems in Engineering
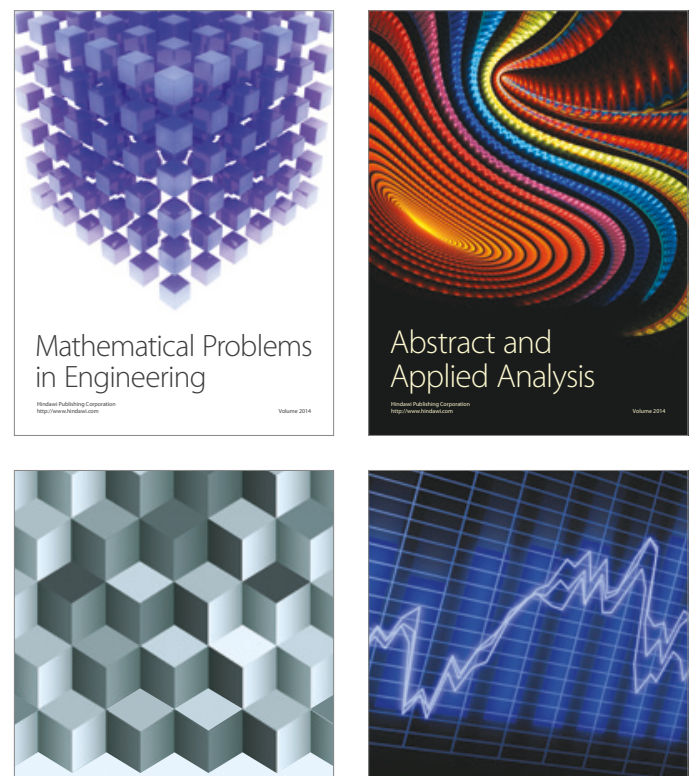

Journal of

Function Spaces

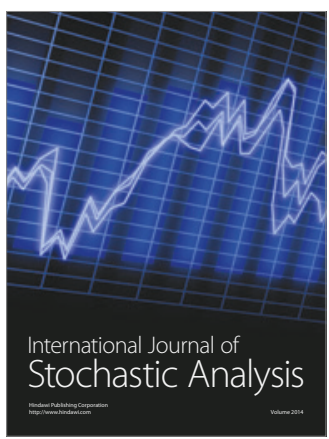

Probability and Statistics
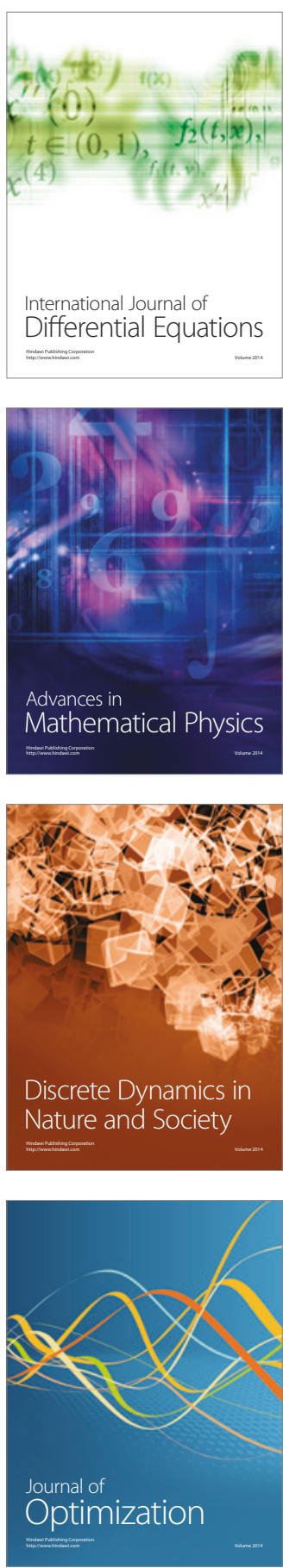